\title{
Regional Economic Analysis of Mecklenburg County, NC
}

\author{
Maryam Khabazi \\ PhD Candidate \\ Department of Geography \& Earth Sciences, University of North Carolina at Charlotte, United States \\ 5.1.2017
}

\section{Regional Scan}

Located in the state of North Carolina, Mecklenburg county is among the ten fastest growing counties in the Unites States (Carmen et al., 2010). As of 2010 census data the population of the county is 919,628 , with an estimated population of $1,034,070$ in 2015 . The city of Charlotte, that covers the most area of Mecklenburg county, is the largest city in NC with close to 700,000 residents, and the seventeenth largest city in the US. Mecklenburg county is part of the NC-SC Metropolitan Statistical Area (MSA) of Charlotte, Concord, Gastonia.

546 square miles $(1,410 \mathrm{~km} 2)$ of Mecklenburg county is land and 22 square miles $(57 \mathrm{~km} 2)$ is water (US Census Bureau). Adjacent counties include: Iredell county, Cabarrus county, Union county, Gaston county, Catawba county, Lincoln county, Lancaster county (SC), and York county (SC).

Charlotte is home of a large banking industry and several Fortune 500 companies (Carmen et al., 2010). The banking industry makes Charlotte the second largest financial center in the US after New York and has one of the highest median wages in the region (Kozar, 2010). Another large industry in Charlotte is finance, insurance, and real estate, and the headquarters of several national corporations located in Charlotte (Bacot, 2008). Five Fortune 500 Companies that have their headquarters in Mecklenburg County are: Bank of America, Nucor, Sonic Automotive, Duke Energy, and Family Dollar (Dollar Tree) (Fortune, 2016).

Education is another large economic sector in North Carolina due to having the largest public school system and a regional state university in this area (Bacot, 2008); these schools include: UNC Charlotte, Davidson College, Queens University, Johnson \& Wales University, Wake Forest University (School of Business) Charlotte Center, Johnson C. Smith University, Southern Evangelical Seminary, Central Piedmont Community College, and Belmont Abbey College. 
Other large employers in Mecklenburg county are Charlotte Mecklenburg Hospital, CharlotteMecklenburg Board of Education, Wells Fargo Bank (A Corp), Bank of America, and US Air Inc (NC Department of Commerce, 2015, $4^{\text {th }}$ quarter).

Charlotte-Douglas International Airport is the main airport in the region that is the 5th busiest airport in the nation in 2015, and the 6th busiest in the world (Portillo, 2016). This airport is the hub for US Airways and American Airlines that have been merged in 2013, to become the second busiest hub for the combined carrier (Portillo, 2015).

Charlotte, like other parts of the US, has been affected by the economic recession that started in 2007. Many job losses and unemployment expanded in all sectors of the economy. The banking industry that was the largest industry in the region was specifically affected by the recession, leaving the region with high unemployment (NC Department of Commerce, 2015, $4^{\text {th }}$ quarter). However, one of the strongest assets of Charlotte economy is its diversity of employment, that even at the time of distress, would sustain its economy (Kozar, 2010).

\section{Population and Labor Force}

\subsection{Overall Trends}

Based on table 2.1., that displays the annualized growth rate and considers the adjustment for difference in time periods, Mecklenburg County population grew at a relatively faster rate during $2000-2010(2.83 \%)$ than $2010-2015(2.37 \%)$. Also, population grew at a relatively faster rate than the state (on average) for both time periods of (00-10 and 10-15).

According to the annualized growth rate of county and state projections for the time periods of 2010-2020 and 2010-2030, Mecklenburg County population will continue to grow in an upward trajectory however this growth is at slightly slower rate than what we have seen in the last few years (10-15) (table 2.1.).

Table 2.1. Annualized Growth Rate in Population,

Source: 2000 and 2010 from the Census (SF1 100\% data); 2015 (ACS) and projections from NC OSBM

\begin{tabular}{|l|r|r|r|r|}
\hline & \multicolumn{4}{|c|}{ Annualized Growth Rate } \\
\hline Area & $2000-2010$ & $2010-2015$ & $2010-2020$ & $2010-2030$ \\
\hline Mecklenburg County & $2.83 \%$ & $2.37 \%$ & $2.21 \%$ & $1.99 \%$ \\
\hline North Carolina & $1.71 \%$ & $1.04 \%$ & $1.05 \%$ & $1.00 \%$ \\
\hline
\end{tabular}


Based on the county migrations statistics 2010-2014, Mecklenburg County is gaining population from migration. The number of inbound migration flows is $71,000(39,495+24,338+7,167)$, while the number of outbound migration flows is $53,764(28,133+25,631)$. These people are coming from different states and also other counties in North Carolina. More specifically, as the map (fig. 1) displays a lot of people are coming from the east and west coasts, and those who are leaving Mecklenburg County are moving mostly to the east and west coasts.

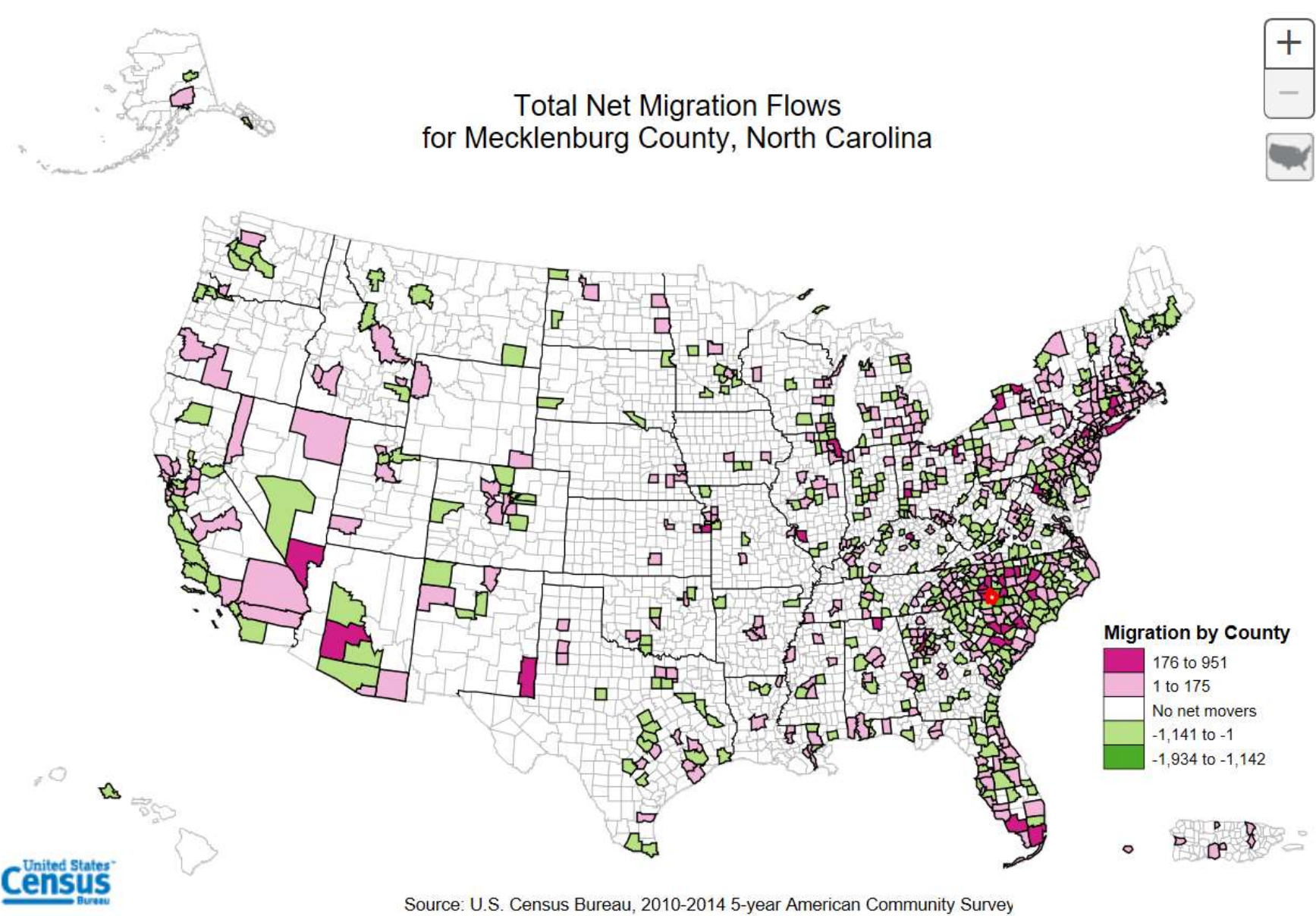

Figure 1: Inbound and Outbound Migration Flows for Mecklenburg County, Source: https://flowsmapper.geo.census.gov/map.html 
Table 2.2.

\section{County Statistics (2010-14)}

Mecklenburg County, North Carolina

Population (1 yr and over): 956,307

Movers from a different state: 39,495

Movers to a different state: 28,133

Movers from a different county, same state: 24,338

Movers to a different county, same state: 25,631

Movers from abroad: 7,167

\subsection{Demographic Changes}

Figure 2.3. displays the change in age distribution in 2010 and 2015 in Mecklenburg County. Based on the graph there are no noteworthy changes have taken place from 2010 to 2015. In other words, the distribution looks very similar in 2015 to what did in 2010.

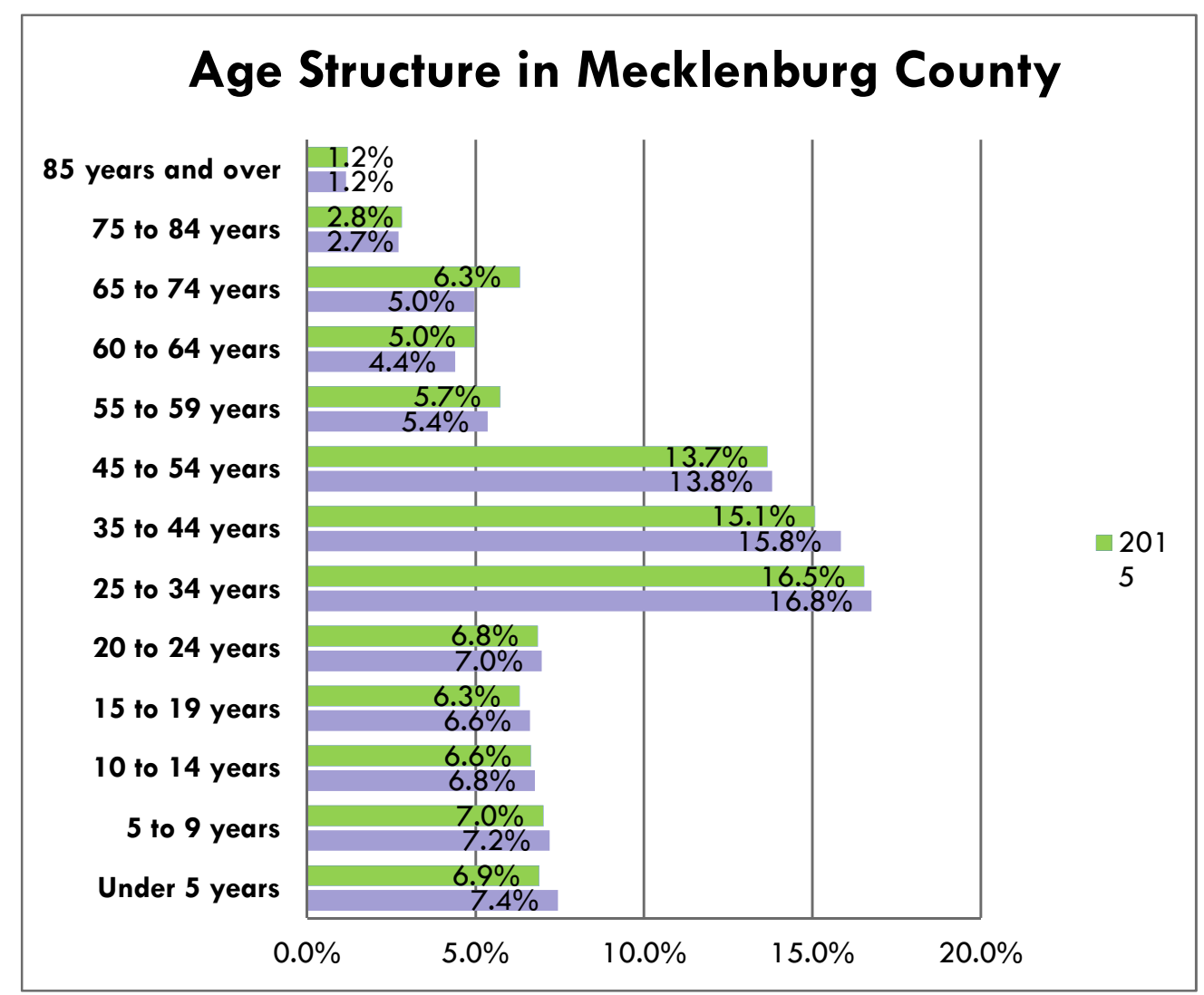

Figure 2.3. Age Structure in Mecklenburg County, Source: 2010 Decennial Census and 2015 from ACS 
Mecklenburg County generally follows national trend in aging population. There are no noteworthy differences between the county and the nation (Fig. 2.5.). It appears that it has a slightly aging population since the percent point change in the county and the US becomes positive for 55 years old and older.

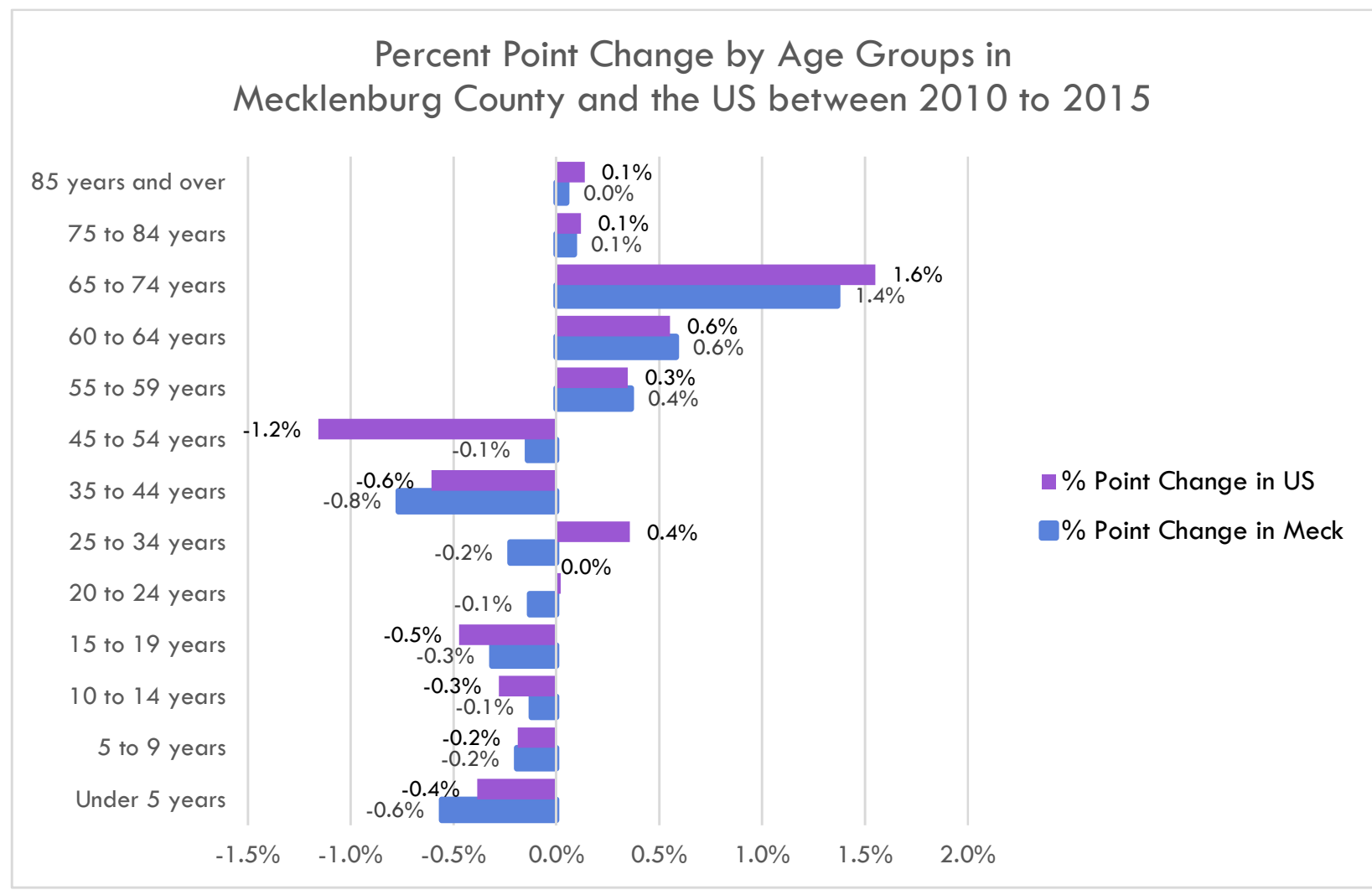

Figure 2.4. Percent Point Change by Age in Mecklenburg County, Source: 2010 Decennial Census and 2015 from ACS 


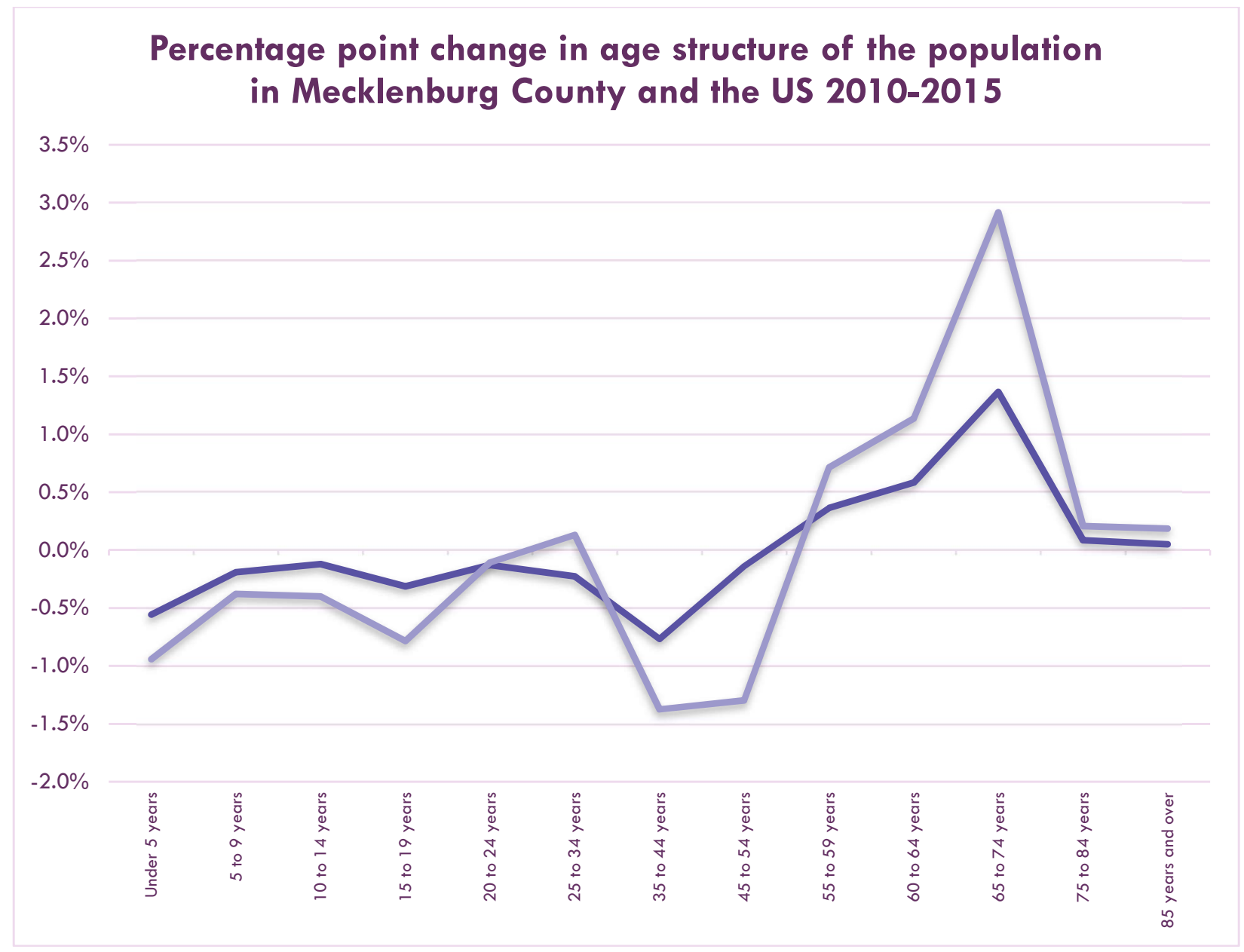

Figure 2.5. Percentage point change in age structure of the population in Mecklenburg County and the US, Source: 2010 Decennial Census and 2015 from ACS.

\subsection{Unemployment and Labor Force Participation Rates}

Based on table 2.6., the unemployment rate in Mecklenburg County follows a similar trend as the state of North Carolina between 2000 and 2015, except from that it is higher by a very small amount of $1 \%$ to $2 \%$. The unemployment rate went up between 2000 and 2010, and one of the reasons for this significant increase is likely the great recession in 2008.

In addition, based on table 2.7., the percentage point change in the unemployment rate displays that the Mecklenburg County had an upward trend in unemployment growth between 2000-2010, however, the trend became opposite between 2010-2015. 
Table 2.6. displays that the labor force participation rate did not change a lot in the time periods of 2000-2015, and it is relatively higher than labor force participation rate in North Carolina (table 2.6.). Additionally, based on table 2.7., percentage point change in labor force participation rate confirms the same conclusion (table 2.7.).

Table 2.6. Comparison of annual unemployment rate and labor force rate for Mecklenburg County and NC in 2000, 2010, and 2015, Source: NC Department of Commerce LAUS

\begin{tabular}{|l|r|r|r|r|r|r|}
\hline & \multicolumn{2}{|c|}{2000} & \multicolumn{2}{c|}{2010} & \multicolumn{2}{c|}{2015} \\
\hline & Meck & NC & Meck & NC & Meck & \multicolumn{1}{|c|}{ NC } \\
\hline Unemployment rate (\%) & $5.17 \%$ & $3.67 \%$ & $12.80 \%$ & $10.85 \%$ & $6.90 \%$ & $5.74 \%$ \\
\hline $\begin{array}{l}\text { Labor force participation } \\
\text { rate (\%) }\end{array}$ & $72.35 \%$ & $65.78 \%$ & $71.90 \%$ & $63.35 \%$ & $71.20 \%$ & $61.05 \%$ \\
\hline
\end{tabular}

Table 2.7. Percentage point change in the unemployment and labor force participation rate between the periods 2000 to 2010 and 2010 to 2015 for Mecklenburg County and NC, Source: NC Department of Commerce LAUS

\begin{tabular}{|l|c|c|c|c|}
\hline & \multicolumn{4}{|c|}{ Percentage/percentage point change } \\
\hline & \multicolumn{2}{|c|}{$2000-2010$} & \multicolumn{2}{c|}{$2010-2015$} \\
\hline Mnemployment rate (\%) & $7.63 \%$ & $\mathrm{NC}$ & Meck & $\mathrm{NC}$ \\
\hline $\begin{array}{l}\text { Labor force participation } \\
\text { rate (\%) }\end{array}$ & $-0.45 \%$ & $-2.18 \%$ & $-5.90 \%$ & $-5.11 \%$ \\
\hline
\end{tabular}

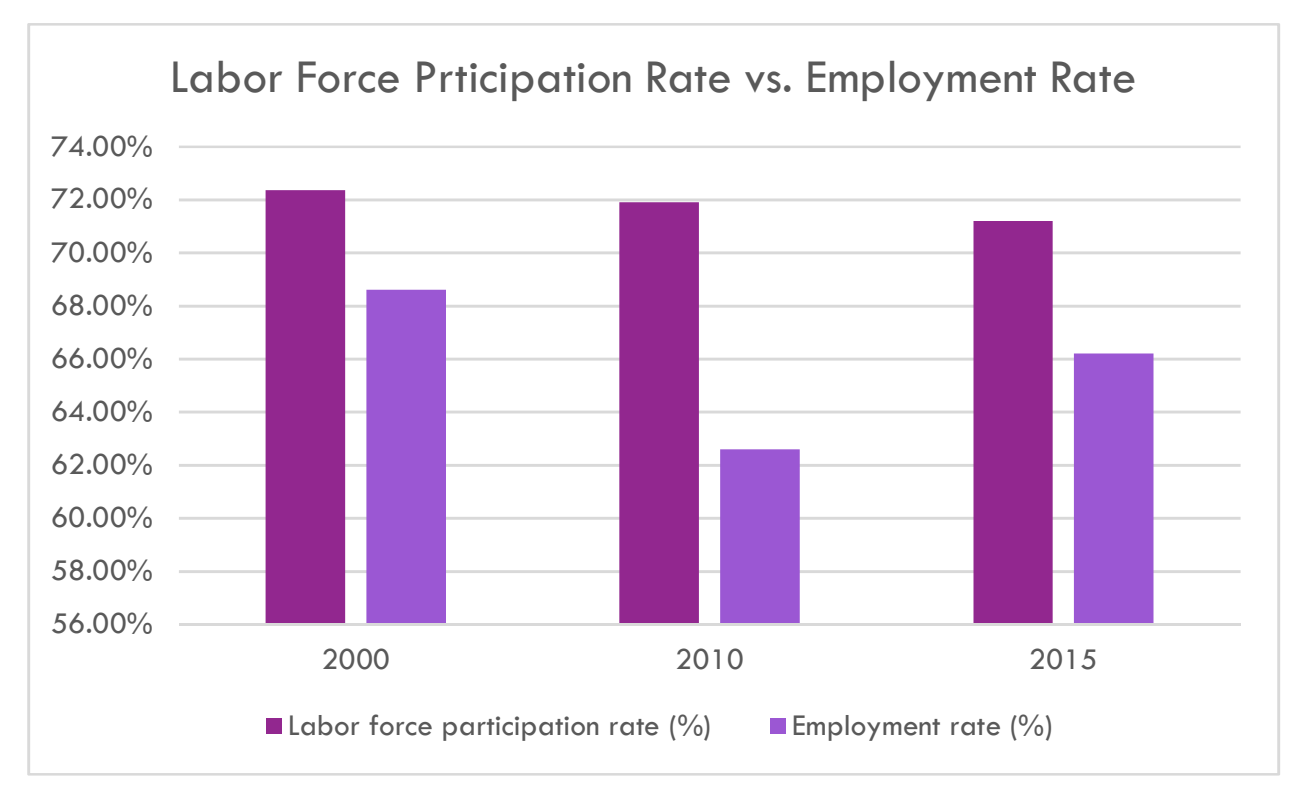

Figure 2.6. Labor Force Participation Rate vs. Employment Rate 


\subsection{Educational Attainment}

Mecklenburg County has improved in terms of educational attainment from 2010 to 2015. Figure 2.7. depicts that in 2015 compared to 2010, percentage of people with at least a bachelor's degree increased by around $4 \%$ and percentage of people with at least High School diploma increased by around $2 \%$. Also, individuals without a high school diploma or equivalent has decreased by around $2 \%$ percent (fig. 2.7.).

Based on figures 2.7. and 2.8., Mecklenburg County in general did better in terms of educational level in 2015 compared with the state of $\mathrm{NC}$, because the percentage of people with at least a bachelors' degree is about $43 \%$ in Mecklenburg county while the same degree level is just $30 \%$ in the State. Also, the percentage of people with at least a High School diploma is $89 \%$ in Mecklenburg county in 2015 while the same level of education is $87 \%$ in the state (fig 2.7. and 2.8.).

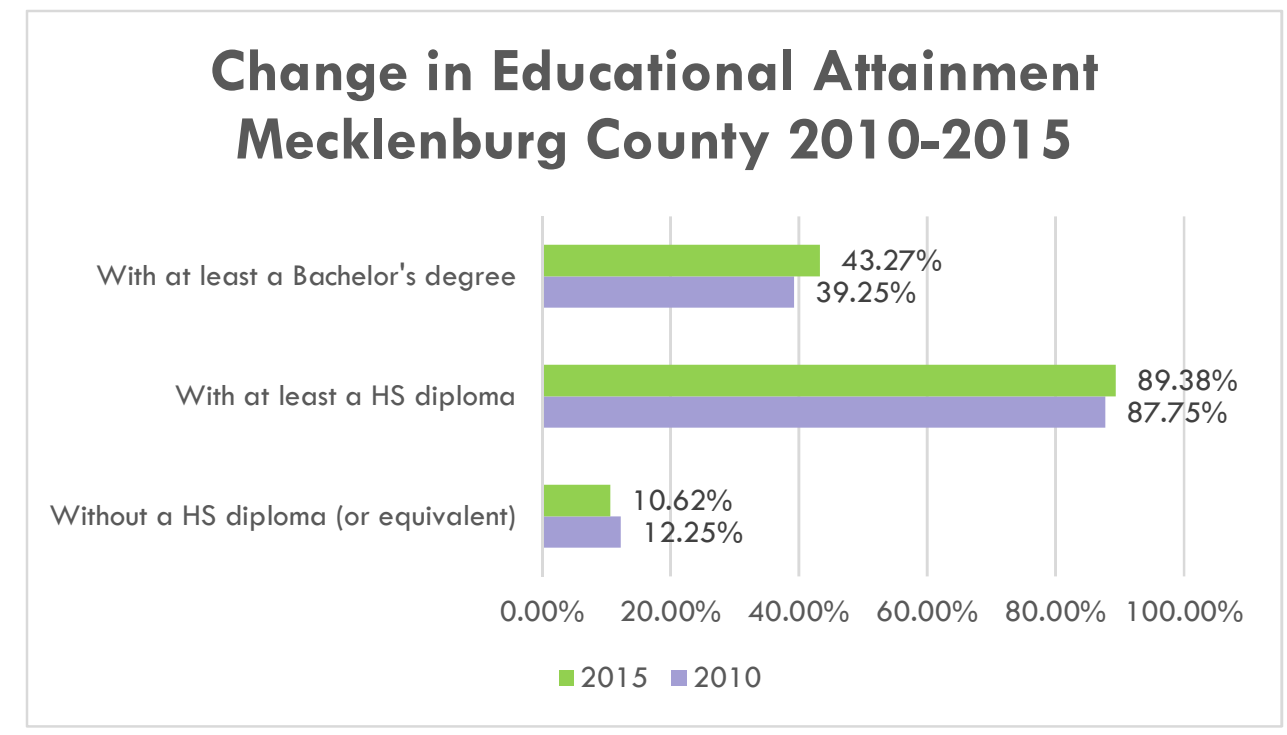

Figure 2.7. Change in Educational Attainment Mecklenburg County 2010-2015, Source: 2010 and 2015 from ACS, Census 


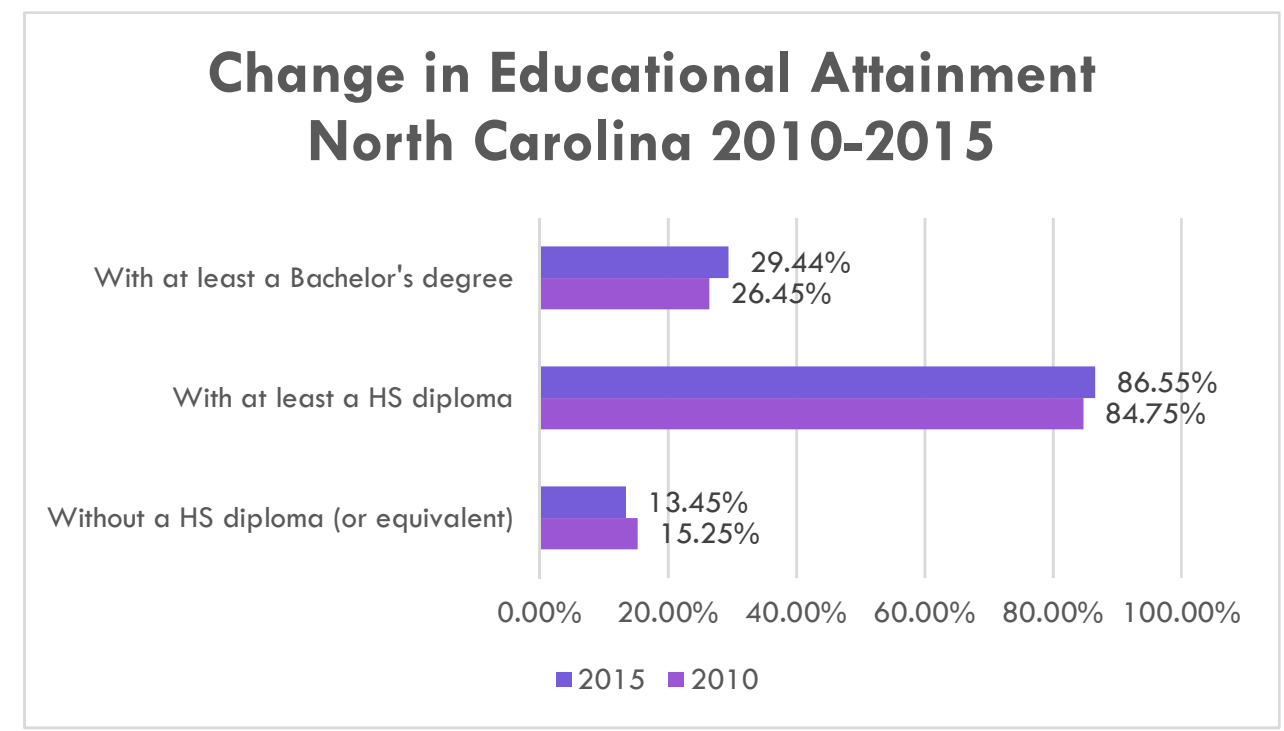

Figure 2.8. Change in Educational Attainment North Carolina 2010-2015

Figures 2.9. and 2.10. display educational attainment in Mecklenburg County and North Carolina in 2015 for people in age of 25 years old and over. These figures also show the better situation of Mecklenburg County in terms of educational attainment in general compared to North Carolina.

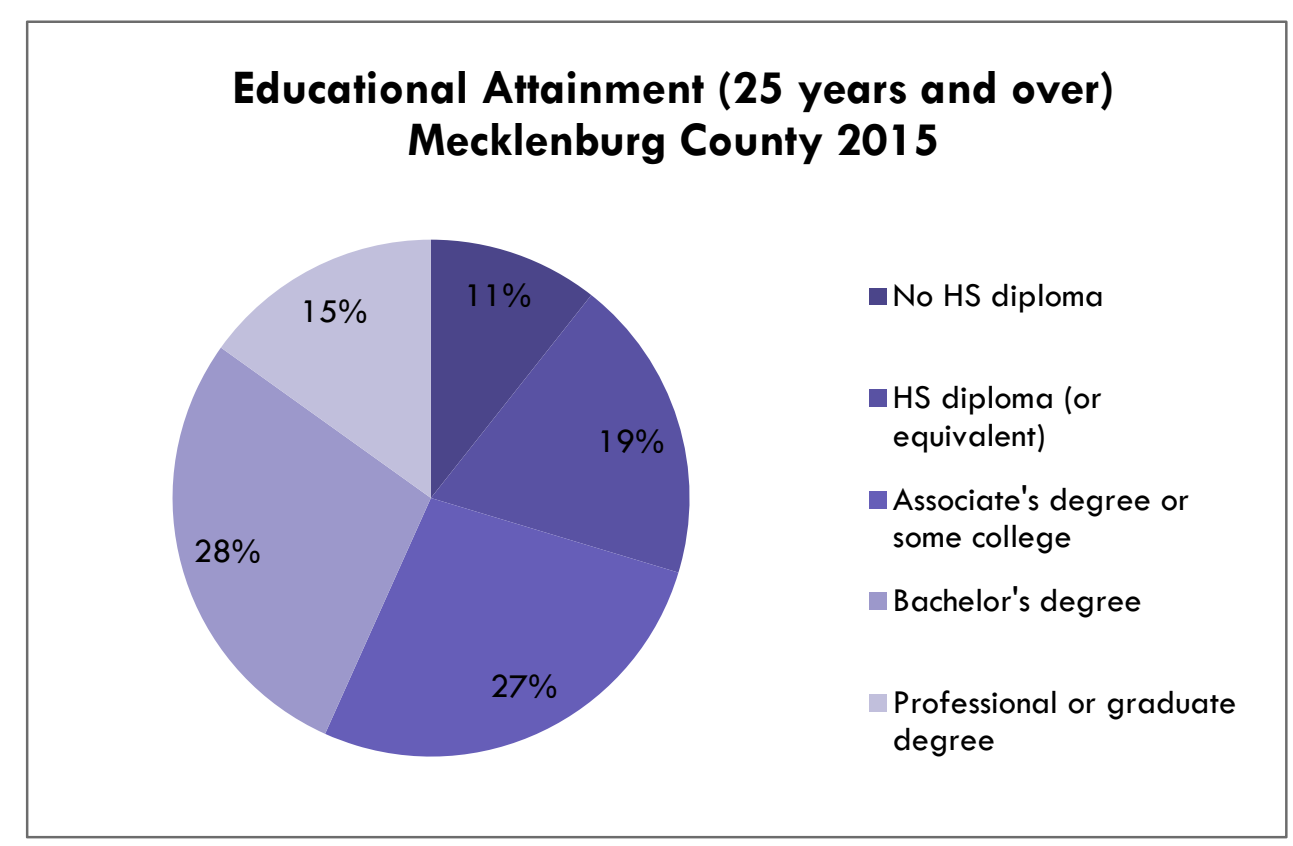

Figure 2.9. Educational Attainment ( 25 years and over) Mecklenburg County 2015, Source: ACS, Census 


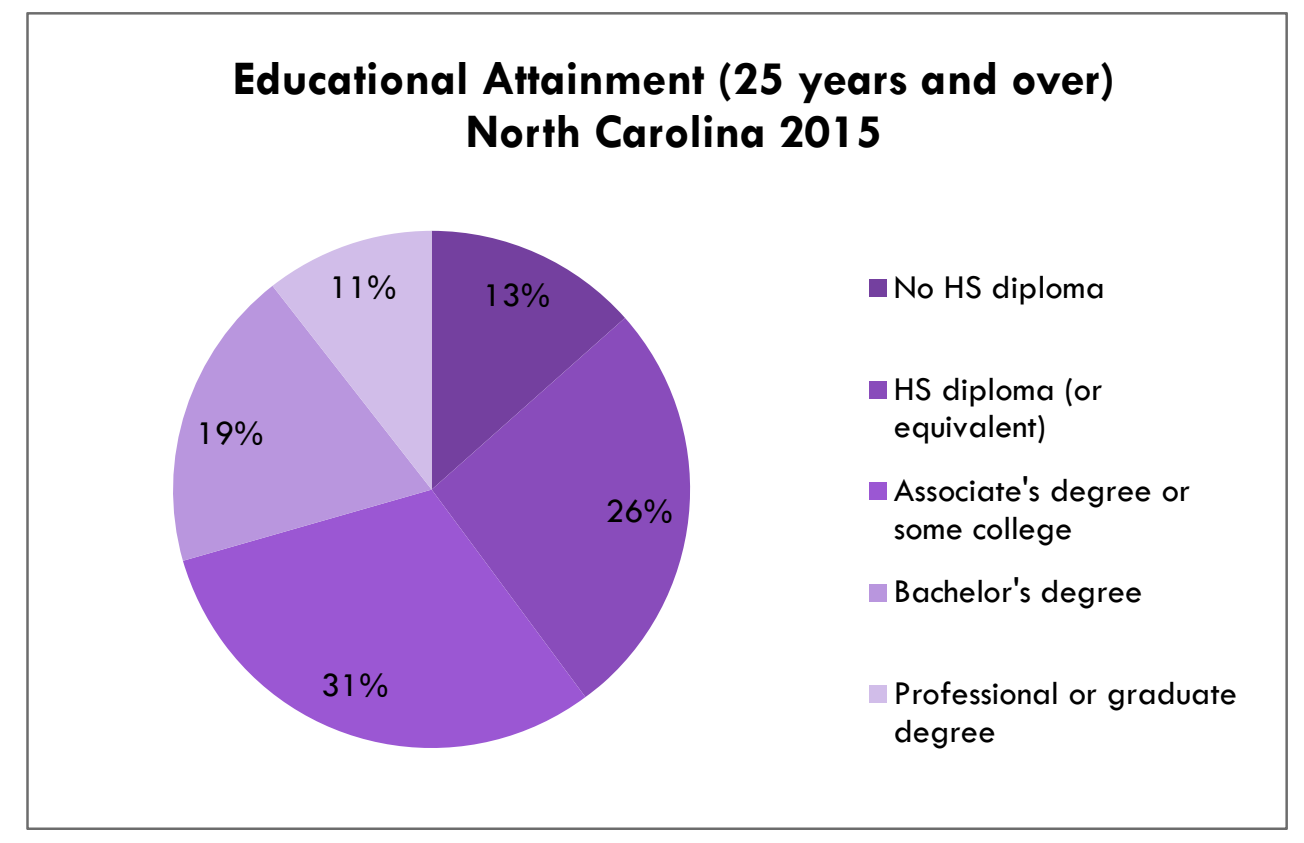

Figure 2.10. Educational Attainment ( 25 years and over) North Carolina 2015

\section{Employment and LQ}

\subsection{Overall Employment Trends}

Based on table 3.1., average annual employment rates and labor force participation rates in all three years of 2000, 2010, and 2015 in Mecklenburg County are higher than the average annual employment rates and labor force participation rates in the state of North Carolina. In 2010, the unemployment rate relatively higher compared to 2000 and 2015.

Table 3.1. Unemployment, Labor Force Participation, and Employment rate in 2000-2010-2015, Source: NC Department of Commerce LAUS

\begin{tabular}{|l|r|r|r|r|r|r|}
\hline & \multicolumn{2}{|c|}{2000} & \multicolumn{2}{c|}{2010} & \multicolumn{2}{c|}{2015} \\
\hline & Meck & NC & Meck & NC & Meck & \multicolumn{1}{c|}{ NC } \\
\hline Unemployment rate (\%) & $5.17 \%$ & $3.67 \%$ & $10.67 \%$ & $10.85 \%$ & $5.36 \%$ & $5.74 \%$ \\
\hline Labor force participation rate (\%) & $72.35 \%$ & $65.78 \%$ & $70.53 \%$ & $63.35 \%$ & $69.67 \%$ & $61.05 \%$ \\
\hline Employment rate (\%) & $68.61 \%$ & $63.37 \%$ & $63.01 \%$ & $56.48 \%$ & $65.93 \%$ & $57.54 \%$ \\
\hline
\end{tabular}

By looking at figure 3.1., employment rate went down from 2000 to 2010, but it grew from 2010 to 2015. However, labor force participation rates have not been changed a lot. Table 3.2. indicates 
that the working age population (16 years old and over) grew proportionally more than the labor force between 2000 and 2010 in Mecklenburg County. Working age population continued to grow more than the labor force between 2010 and 2015. Meaning that even if the working age population grew, few of them joined the labor force.

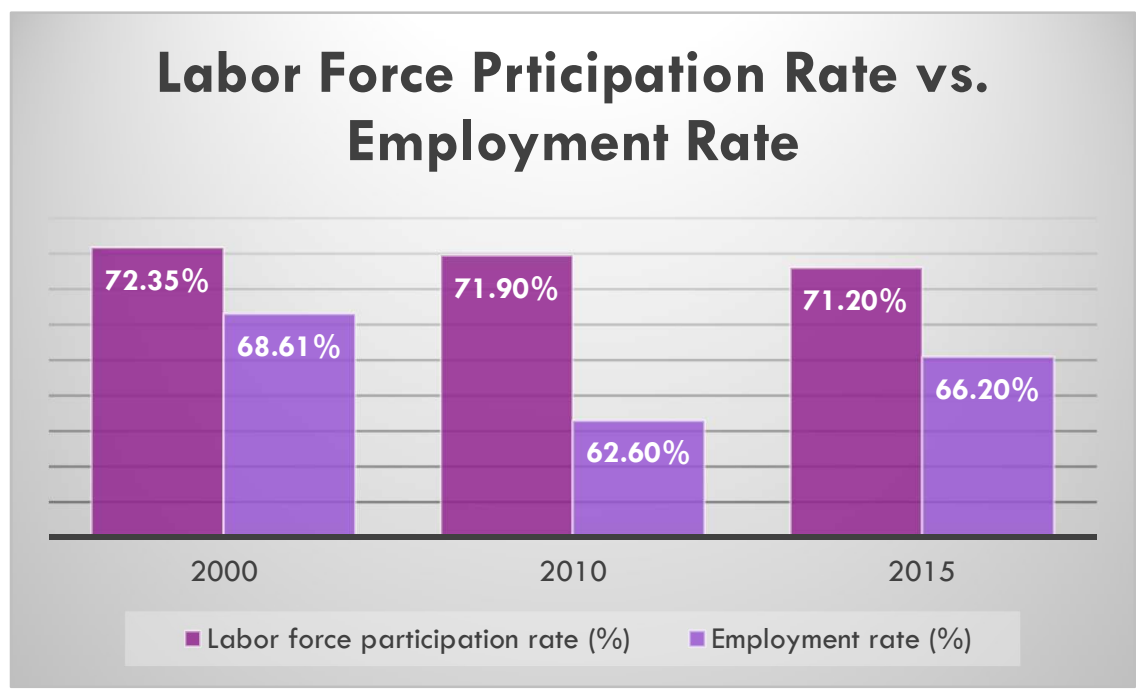

Figure 3.1. Labor Force Participation vs. Employment Rate

In table 3.2., considering the percentage point change in (unadjusted) employment between the periods 2000-2010 and 2010-2015 for Mecklenburg County and North Carolina, we can see that employment rate growth was negative in 2000-2010 and positive in 2010-2015. While the unemployment rate went down between 2010 and 2015, so did the labor force participation rate.

While Mecklenburg County employment trend follows the NC fairly closely, it has seen a relatively larger working age population (as well as labor force) increase in the two-time periods.

Table 3.2. Percent Point Change in Unemployment, Labor Force Participation, and Employment rate for 2000-2010, and 2010-2015, Source: NC Department of Commerce LAUS

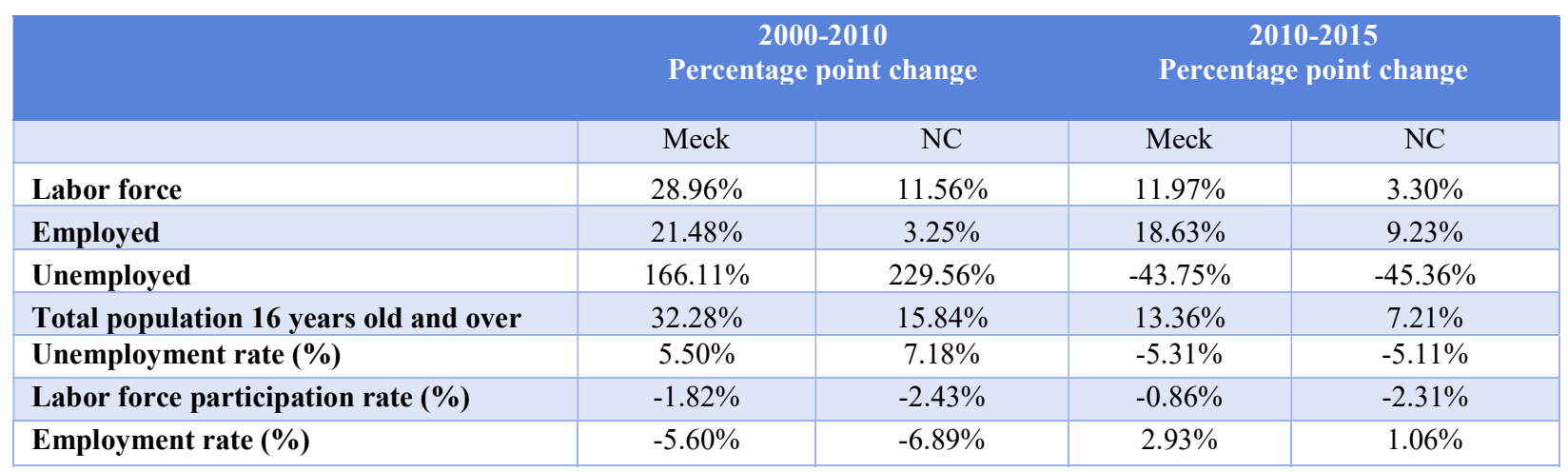




\subsection{Industrial Composition}

Table 3.3. displays the top 5 private nonfarm industries in terms of share of employment in Mecklenburg County in 2001 and 2015. As it is displayed, there is a jump to the first level for finance and insurance sector in terms of share of employment. Also, professional, scientific and technical services, and accommodation and food services jumped to the top 5 industries in 2015 compared to 2001 in Mecklenburg County.

Table 2.3. Top 5 private nonfarm industries in share of employment in Mecklenburg County in 2001 and 2015 , Source: BEA Regional Data

\begin{tabular}{|c|c|}
\hline Top 5 (2001): & Top 5 (2015): \\
\hline Retail trade & Finance and insurance \\
\hline Finance and insurance & Retail trade \\
\hline $\begin{array}{l}\text { Administrative and support and waste management } \\
\text { and remediation services }\end{array}$ & $\begin{array}{l}\text { Administrative and support and waste management } \\
\text { and remediation services }\end{array}$ \\
\hline Manufacturing & Professional, scientific, and technical services \\
\hline Professional, scientific, and technical services & Accommodation and food services \\
\hline
\end{tabular}

Figure 3.2. displays share of private nonfarm employment by industry in Mecklenburg County in 2001, 2010, and 2015. Share of construction, manufacturing, wholesale trade, and retail trade went down from 2001 to 2015. However, the share of some other industries such as finance and insurance, accommodation and food services, professional, scientific, and technical services, real estate and rental and leasing grew from 2001 to 2015. 


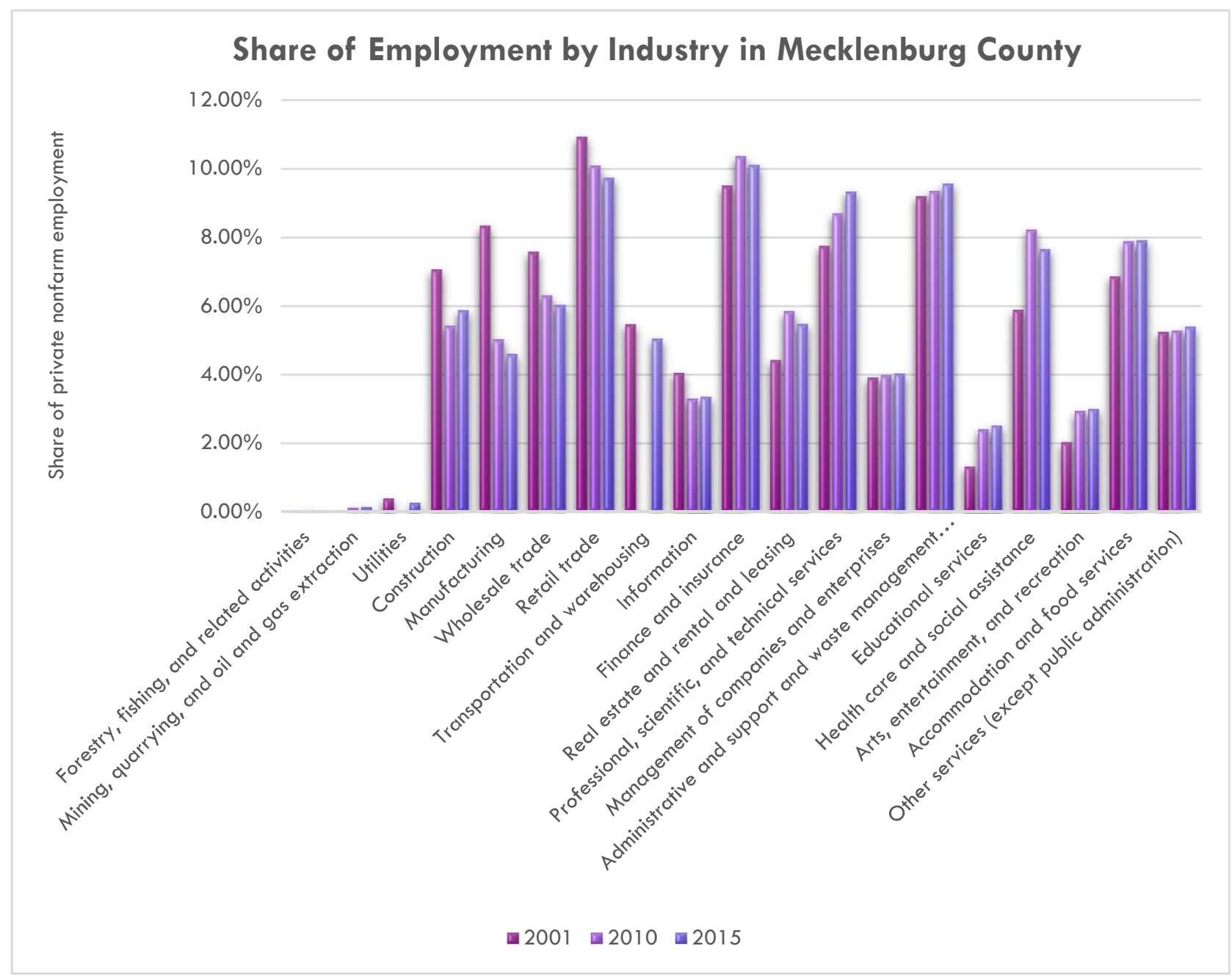

Figure 3.2. Employment by Industry in Mecklenburg County, Source: BEA Regional Data

\subsection{Location Quotients}

Table 3.4. shows location quotients for Mecklenburg County and North Carolina (with US as reference area) in 2015 for 2-digit nonfarm industries. As you can see management of companies and enterprises by Location Quotient of 2.70 has the highest LQ in the county, it showed a low share of employment in the county in 2015. The second position is for Finance and insurance by Location Quotient of 1.71 which already had the highest share of employment in 2015 and has comparatively large presence in Mecklenburg County. And the third industry is information with LQ of 1.62. So, these three industries in the region have higher concentration than the nation. 
On the other hand, Forestry, fishing, and related activities with a Location Quotient of 0.09, and Mining, quarrying, and oil and gas extraction with a Location Quotient of 0.15 have relatively smaller presence in Mecklenburg County in 2015 compared to the nation.

It is interesting to pay attention that Finance and insurance, and Professional, scientific, and technical services that have relatively low LQ in North Carolina, have relatively high LQ in Mecklenburg. It means that most of the employment in Finance and insurance, and Professional, scientific, and technical services in the State of North Carolina is concentrated in Mecklenburg County.

The largest share of employment in Mecklenburg County in 2015 is in the Finance and Insurance Industry with 77,102 jobs. The following industry is retail trade with 74,248 jobs.

Table 3.4. Location Quotient Mecklenburg County and NC for 2-digit nonfarm industries in 2015

\begin{tabular}{|c|c|c|c|c|}
\hline Location Quotients & $\begin{array}{c}\text { Employment } \\
2015\end{array}$ & LQ & $\begin{array}{c}\text { Employment } \\
2015 \\
\end{array}$ & LQ \\
\hline & Meck & LQ & NC & LQ \\
\hline Private nonfarm employment & 763086 & - & 4783768 & - \\
\hline Forestry, fishing, and related activities & 403 & 0.09 & 26711 & 0.95 \\
\hline Mining, quarrying, and oil and gas extraction & 1029 & 0.15 & 8523 & 0.19 \\
\hline Utilities & 2056 & 0.75 & 15087 & 0.88 \\
\hline Construction & 44789 & 0.96 & 318501 & 1.09 \\
\hline Manufacturing & 35080 & 0.57 & 484595 & 1.26 \\
\hline Wholesale trade & 45931 & 1.45 & 204929 & 1.03 \\
\hline Retail trade & 74248 & 0.83 & 589655 & 1.05 \\
\hline Transportation and warehousing & 38475 & 1.25 & 162547 & 0.84 \\
\hline Information & 25576 & 1.62 & 92196 & 0.93 \\
\hline Finance and insurance & 77102 & 1.71 & 245660 & 0.87 \\
\hline Real estate and rental and leasing & 41755 & 1.02 & 246232 & 0.96 \\
\hline Professional, scientific, and technical services & 71173 & 1.15 & 336806 & 0.87 \\
\hline Management of companies and enterprises & 30704 & 2.70 & 86979 & 1.22 \\
\hline $\begin{array}{l}\text { Administrative } \& \text { support } \& \text { waste } \\
\text { management and remediation services }\end{array}$ & 72896 & 1.30 & 403002 & 1.15 \\
\hline Educational services & 19174 & 0.88 & 131690 & 0.96 \\
\hline Health care and social assistance & 58381 & 0.59 & 557152 & 0.89 \\
\hline Arts, entertainment, and recreation & 22850 & 1.14 & 120973 & 0.96 \\
\hline Accommodation and food services & 60337 & 0.92 & 423852 & 1.03 \\
\hline Other services (except public administration) & 41127 & 0.80 & 328678 & 1.02 \\
\hline
\end{tabular}




\section{Earnings and Income}

\subsection{Comparison of Earnings Trends}

Figure 4.1. visualizes the change in Mecklenburg County's share of earnings by industry for all private nonfarm employment for the years 2001, 2010 and 2015. In other words, it displays industry earnings as percentage of total local private nonfarm earnings. Based on figure 4.1. Finance and insurance, Professional, scientific, and technical services, and Management of companies and enterprises have the highest share of earnings in Mecklenburg County in 2015.

By comparing the share of earning trends with the share of employment trends by industry in Mecklenburg County, (fig. 4.1. and 3.2.) we can see that finance and insurance is the top one for both. However, while Professional, scientific, and technical services, Management of companies and enterprises, wholesale trade, and Construction made to the top 5 in earnings, just the Professional, scientific, and technical services are also in top 5 employment in Mecklenburg County in 2015.

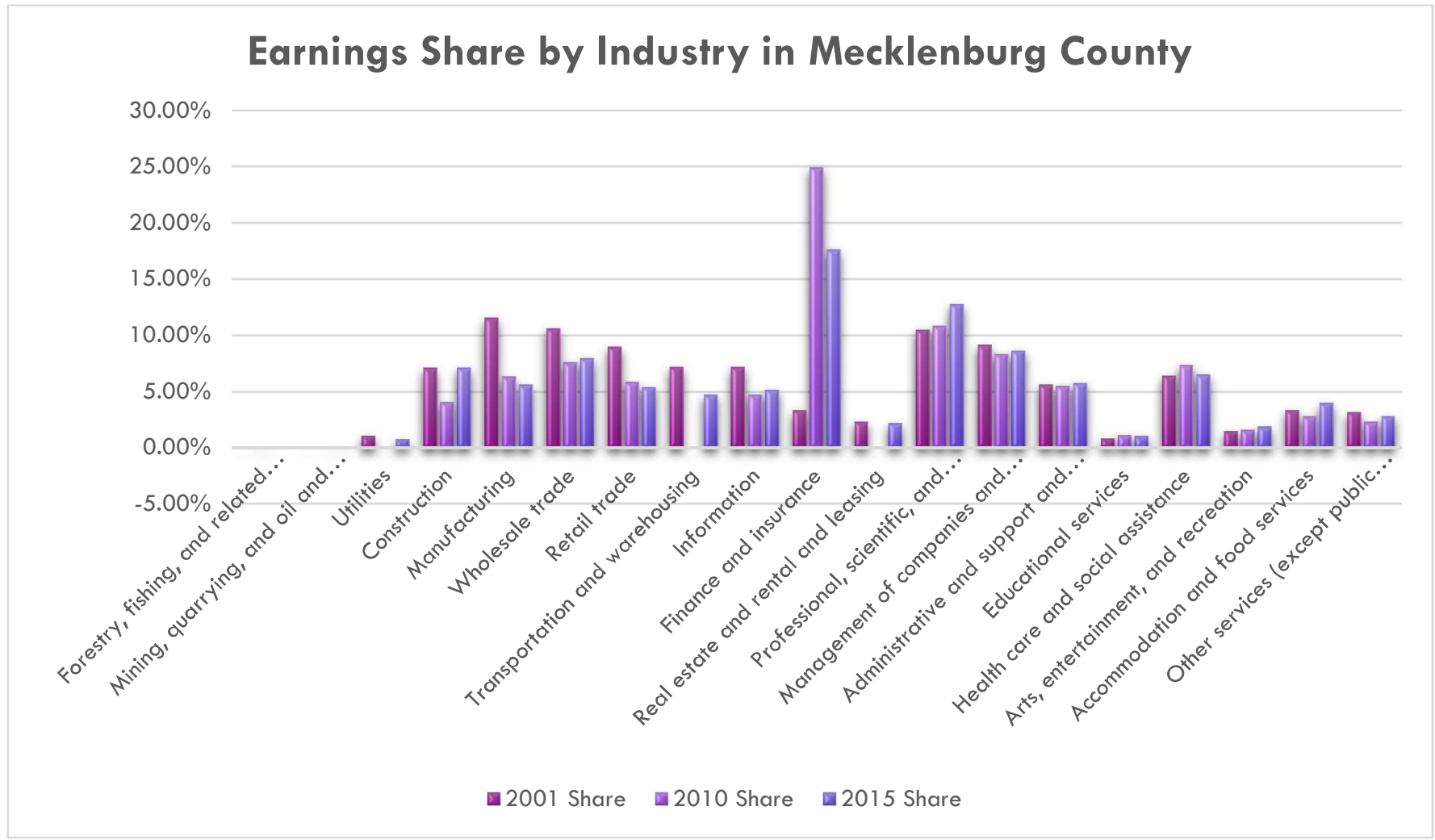

Figure 4.1. Share of earning by industry in Mecklenburg County in 2001-2010-2015 
Table 4.1. summarizes top 5 industries in terms of share of earnings in 2001-2010-2015.

Table 4.3. Top 5 Earnings by Industry in 2001-2010-2015

\begin{tabular}{|l|l|l|}
\hline 2001 share & $\mathbf{2 0 1 0}$ share & 2015 share \\
\hline $\begin{array}{l}\text { 1. Manufacturing } \\
\text { 2. Wholesale trade }\end{array}$ & $\begin{array}{l}\text { 1. Finance and insurance } \\
\text { technical services }\end{array}$ & $\begin{array}{l}\text { 1. Finance and insurance } \\
\text { 2. Professional, scientific, and } \\
\text { technical services }\end{array}$ \\
\hline $\begin{array}{l}\text { 3. Professional, scientific, and } \\
\text { technical services }\end{array}$ & $\begin{array}{l}\text { 3. Management of companies } \\
\text { and enterprises }\end{array}$ & $\begin{array}{l}\text { 3. Management of companies } \\
\text { and enterprises }\end{array}$ \\
\hline $\begin{array}{l}\text { 4. Management of companies } \\
\text { and enterprises }\end{array}$ & 4. Wholesale trade & 4. Wholesale trade \\
\hline 5. Retail trade & $\begin{array}{l}\text { 5. Health care and social } \\
\text { assistance }\end{array}$ & 5. Construction \\
\hline
\end{tabular}

Tables 4.2. and 4.3. compare the earnings trends in Mecklenburg County with employment trends by industry in this same region in 2001 and 2015. Just considering table 4.3. in 2015, you can see that Finance and insurance is on top for employment and earnings in Mecklenburg County. While the second top employment is Retail trade, the top earnings is Professional, scientific, and technical services. Moreover, Administrative and support and waste management and remediation services is the third employment, while the third earning category is Management of companies and enterprises.

Table 4.2. Top 5 Employment vs. Earnings 2001 (Source: BEA) Top 5 Employment vs. Earnings 2001

Retail vs. Manufacturing

Finance vs. Wholesale trade

Admin. vs. Professional, scientific, and technical services Manufacturing vs. Management of companies and enterprises

Wholesale trade vs. Retail trade

Table 4.3. Top 5 Employment vs. Earnings 2015 (Source: BEA) Top 5 Employment vs. Earnings 2015

Finance and insurance vs. Finance and insurance

Retail vs. Professional, scientific, and technical services

Admin. vs. Management of companies and enterprises

Professional, Scientific. vs. Wholesale trade

Accommodation vs. Construction 


\subsection{Wage and Employment Trends by Occupation}

Based on the data from North Carolina Department of Commerce's Labor \& Economic Analysis Division that has data on estimated employment and median annual wage for Mecklenburg County for each occupation categories in the years 2001 and 2015, we can see that the top 5 growing occupations in Mecklenburg County are Business \& Financial Operations, Computer and Mathematical, Protective Service, Sales \& Related, Healthcare Practitioners and Technical (table 4.4.). It is important to mention that while Protective Service made the top 5 growing occupations in Mecklenburg County, the median annual wage of this occupation has been declining (-1.40\%).

Table 4.4. Growing Occupations in terms of employment 2001-2015, Source: calculated from the data in North Carolina Department of Commerce's Labor \& Economic Analysis Division

\begin{tabular}{|l|r|r|}
\hline \multicolumn{1}{|c}{ Growing Occupations } & Wage Change \\
\hline 1. Business \& Financial Operations & $\mathbf{3 . 8 9} \%$ & $25.82 \%$ \\
\hline 2. Computer and Mathematical & $\mathbf{2 . 0 5 \%}$ & $11.74 \%$ \\
\hline 3. Protective Service & $\mathbf{1 . 9 3 \%}$ & $-1.40 \%$ \\
\hline 4. Sales \& Related & $\mathbf{1 . 4 7 \%}$ & $5.27 \%$ \\
\hline 5. Healthcare Practitioners and Technical & $\mathbf{1 . 1 5 \%}$ & $8.37 \%$ \\
\hline
\end{tabular}

On the other hand, table 4.5 depicts 5 declining occupations in terms of employments in Mecklenburg County. These 5 occupations are Office and Administrative Support, Management, Production, Construction and Extraction, and Building \& Grounds Cleaning \& Maintenance. Although Office and Administrative Support, Management, and Production are declining in terms of number of employments, their wage change is positive. Specifically, management that has $42.56 \%$ increase in its wage.

Table 4.5. Declining Occupation in terms of employment 2001-2015, Source: calculated from the data in North Carolina Department of Commerce's Labor \& Economic Analysis Division

\begin{tabular}{|l|r|r|}
\hline \multicolumn{1}{|c|}{ Declining Occupations } & Wage Change \\
\hline 1. Office and Administrative Support & $\mathbf{- 3 . 5 9 \%}$ & $5.96 \%$ \\
\hline 2. Management & $\mathbf{- 2 . 7 5 \%}$ & $42.56 \%$ \\
\hline 3. Production & $\mathbf{- 2 . 7 4 \%}$ & $0.96 \%$ \\
\hline 4. Construction and Extraction & $\mathbf{- 1 . 7 6 \%}$ & $-1.33 \%$ \\
\hline 5. Building \& Grounds Cleaning \& Maint. & $\mathbf{- 0 . 5 3 \%}$ & $-8.54 \%$ \\
\hline
\end{tabular}


Figure 4.2. visualizes the occupational mix of Mecklenburg County in 2015. Based on figure 4.2, we can extract top 5 dominant occupations in Mecklenburg County in 2015 (table 4.6.). These occupations are Office and Administrative Support Occupations, Sales and Related Occupations,

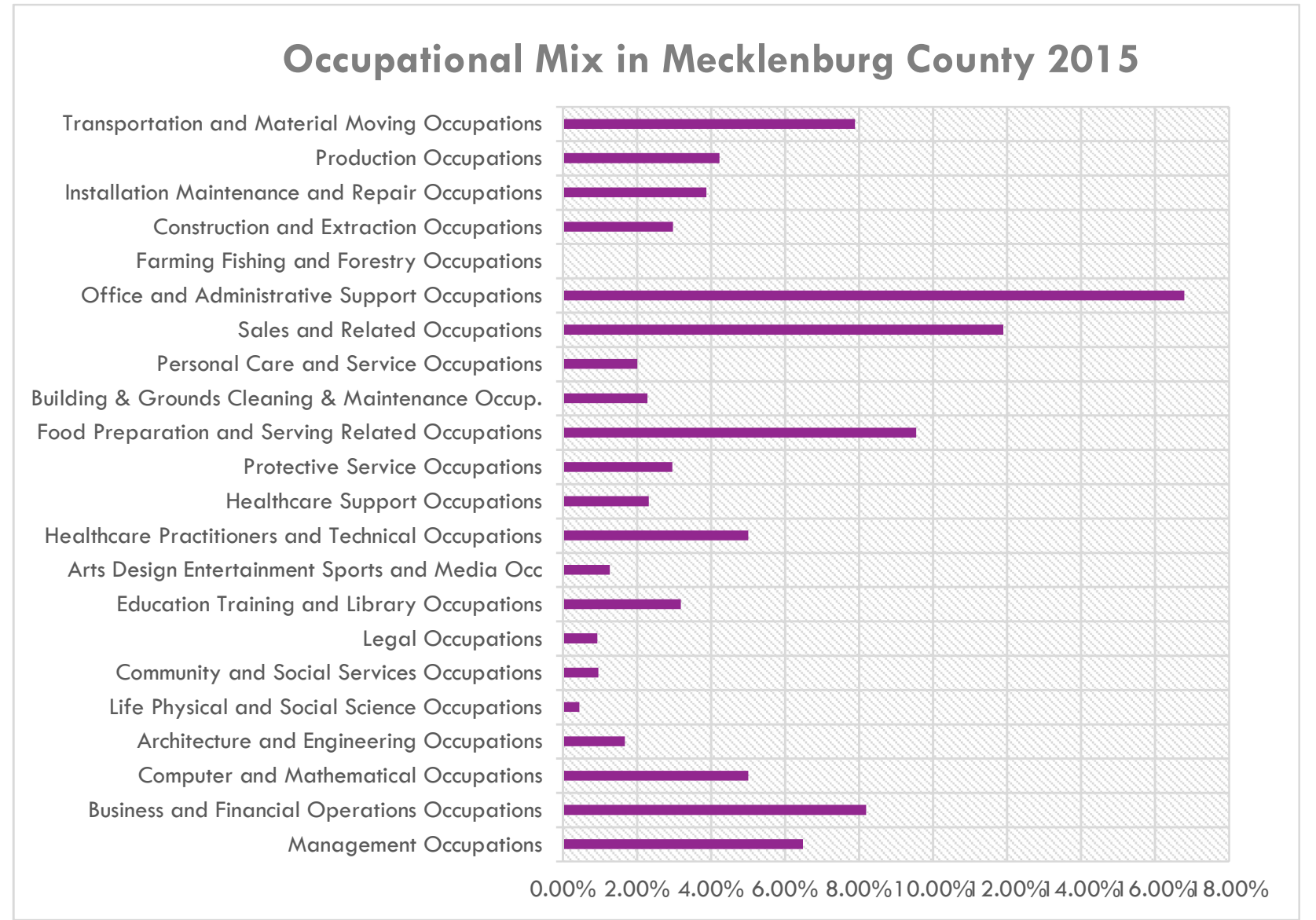

Figure 4.2. Occupational Mix in Mecklenburg County 2015, Source: calculated from the data in North Carolina Department of Commerce's Labor \& Economic Analysis Division

Food Preparation and Serving Related Occupations, Business and Financial Operations Occupations, and transportation and Material Moving Occupations.

Table 4.6. Largest occupation categories in Mecklenburg County in 2015, Source: calculated from the data in North Carolina Department of Commerce's Labor \& Economic Analysis Division

\begin{tabular}{|l|r|r|}
\hline Largest Occupation Categories 2015 & $\begin{array}{l}\text { Employment Share } \\
\text { (Change) }\end{array}$ & $\begin{array}{l}\text { Median Annual Wage } \\
\text { \$2010 (Change) }\end{array}$ \\
\hline 1. Office and Administrative Support Occupations & $16.79 \%(-3.59 \%)$ & $\$ 31,934.90(5.96 \%)$ \\
\hline 2. Sales and Related Occupations & $11.90 \%(1.47 \%)$ & $\$ 30,160.85(5.27 \%)$ \\
\hline $\begin{array}{l}\text { 3. Food Preparation and Serving Related } \\
\text { Occupations }\end{array}$ & $9.55 \%(-0.01 \%)$ & $\$ 17,580.90(-6.28)$ \\
\hline 4. Business and Financial Operations Occupations & $8.19 \%(3.89 \%)$ & $\$ 64,736.53(25.82)$ \\
\hline 5. Transportation and Material Moving Occupations & $7.89 \%(-0.31 \%)$ & $\$ 29,366.12(2.13 \%)$ \\
\hline
\end{tabular}


Tables 4.7. and 4.8. display the top 5 occupations with increasing and decreasing trends in their median wage percent change. It is insightful to consider that while the median wage in Management and Architecture and Engineering is increasing, their employment changes are negative. This might indicate that labor supply has not kept up with labor demand, pushing wages up. Also, based on table 4.8. while the median wage in Legal, Healthcare Support, and Personal Care \& Service is decreasing, their employment increase slightly.

Table 4.7. Top 5 occupations with increasing trend in their median wage percent change, Source: North Carolina Department of Commerce's Labor \& Economic Analysis Division

\begin{tabular}{|l|r|r|}
\hline \multicolumn{1}{|c|}{ Increasing Median Wage } & Employment Change \\
\hline 1. Management & $42.56 \%$ & $-2.75 \%$ \\
\hline 2. Farming, Fishing, and Forestry & $31.86 \%$ & $0.03 \%$ \\
\hline 3. Business and Financial Operations & $25.82 \%$ & $3.89 \%$ \\
\hline 4. Architecture and Engineering & $17.20 \%$ & $-0.46 \%$ \\
\hline 5. Community \& Social Services & $12.51 \%$ & $0.04 \%$ \\
\hline
\end{tabular}

Table 4.8. Top 5 occupations with decreasing trend in their median wage percent change, Source: North Carolina Department of Commerce's Labor \& Economic Analysis Division

\begin{tabular}{|l|r|r|}
\hline \multicolumn{2}{|c|}{ Decreasing Median Wage } & Employment Change \\
\hline 1. Legal & $-48.11 \%$ & $0.02 \%$ \\
\hline 2. Healthcare Support & $-20.26 \%$ & $0.06 \%$ \\
\hline 3. Personal Care \& Service & $-12.53 \%$ & $0.89 \%$ \\
\hline $\begin{array}{l}\text { 4. Building \& Grounds Cleaning \& } \\
\text { Maint. }\end{array}$ & $-8.54 \%$ & $-0.53 \%$ \\
\hline $\begin{array}{l}\text { 5. Food Preparation and Serving } \\
\text { Related }\end{array}$ & $-6.28 \%$ & $-0.01 \%$ \\
\hline
\end{tabular}




\section{Economic Base Analysis}

In this section, we analyze the economic base of Mecklenburg County based on making employment comparisons, analyzing industrial structure, and studying industry growth patterns, and doing some location quotients analysis for Mecklenburg County, North Carolina.

Figure 5.1. displays the 2015 LQ for each industry (x-axis) against the change in LQ for each industry between 2001 and 2015 (y-axis) in Mecklenburg County. The relative size of each bubble shows the number of employees within each respective industry in Mecklenburg County in 2015. In 2015, the highest LQs are respectively for Management, Finance, Info, and Wholesale, which show those industries that have a relatively larger presence in the local economy of Mecklenburg County by having LQ $>1.25$. A high location quotient in a specific industry may mean there is a competitive advantage in that industry for the local economy. The share of employment in these industries is relatively higher than the nation.

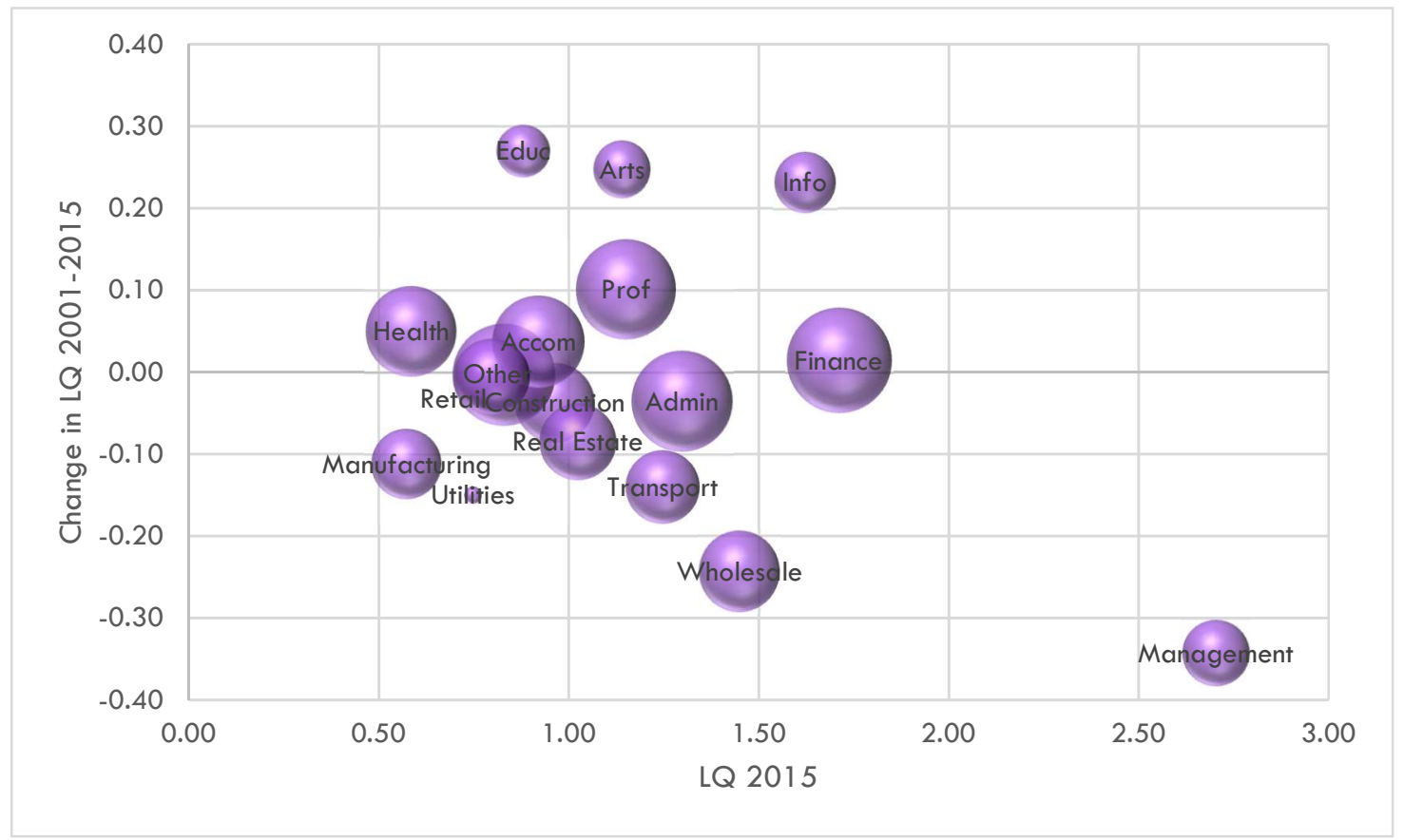

Figure 5.3. 2015 LQ for each industry against the change in LQ for each industry between 2001 and 2015 in Mecklenburg County, Source: BEA 
Looking back at previous sections, based on table 4.3. the highest earning industries in Mecklenburg County are Finance and insurance, Professional, scientific, and technical services, Management, Wholesale trade, and Construction. While the highest employment industries are Finance and insurance, Retail trade, Administrative and support and waste management and remediation services, Professional, scientific, and technical services, and Accommodation and food services.

On the other hand, however, the growing occupations in terms of employment are Business \& Financial Operations, Computer and Mathematical, Protective Service, Sales \& Related, Healthcare Practitioners and Technical (table 4.4.). And the growing occupations in terms of their median wage are Management, Farming, fishing, and forestry, Business and financial operations, Architecture and engineering, and Community and social services (table 4.7.).

Moreover, based on figure 5.1., the highest increase in LQ (or change in LQ) is respectively for Education, Arts, Info, Professional, scientific, and technical services, and health and it displays the relative concentration of these industries in the Mecklenburg County economy (fig 5.1.).

Since we assume those industries with LQi $<1$ are non-basic industries, consequently utility, construction, manufacturing, retail, education, health, and accommodation are considered nonbasic industries for Mecklenburg County.

Therefore, based on these comparisons and analyses, industries that showed up in more than one category are Professional, scientific, and technical services, Finance and insurance, Management of companies and enterprises, Business \& Financial Operations. 


\section{Target Industry Analysis}

\subsection{Top 25 industries in four metrics of economic activity}

Considering four metrics of economic activity; total industrial output, employment, labor income, and total value added, fifteen industries made the top 25 industries in all four metrics of economic activity (table 6.1).

Table 6.1. Fifteen industries in top 25 industries in all four metrics of economic activity, Source: industry summary data IMPLAN

\begin{tabular}{|c|c|c|c|c|c|c|c|c|c|}
\hline Sector & Industry & Output (\$) & $\begin{array}{l}\text { Share } \\
\text { of } \\
\text { Total } \\
(\%)\end{array}$ & $\begin{array}{l}\text { Employ } \\
\text { ment }\end{array}$ & $\begin{array}{l}\text { Share } \\
\text { of } \\
\text { Total } \\
(\%)\end{array}$ & Income (\$) & $\begin{array}{l}\text { Share } \\
\text { of } \\
\text { Total } \\
(\%)\end{array}$ & $\begin{array}{l}\text { Total Value } \\
\text { Added (\$) }\end{array}$ & $\begin{array}{c}\text { Share } \\
\text { of } \\
\text { Total } \\
(\%)\end{array}$ \\
\hline 395 & Wholesale trade & 9328416992 & $12.4 \%$ & 41857 & $10.5 \%$ & 3485928589 & $10.9 \%$ & 6191266846 & $19.3 \%$ \\
\hline 411 & Truck transportation & 1658724121 & $2.2 \%$ & 10457 & $2.6 \%$ & 605178665.2 & $1.9 \%$ & 741947359.1 & $2.3 \%$ \\
\hline 433 & $\begin{array}{l}\text { Monetary authorities and } \\
\text { depository credit } \\
\text { intermediation }\end{array}$ & 9450167969 & $12.6 \%$ & 25592 & $6.4 \%$ & 3355082397 & $10.5 \%$ & 7120356552 & $22.2 \%$ \\
\hline 434 & $\begin{array}{l}\text { Nondepository credit } \\
\text { intermediation and related } \\
\text { activities }\end{array}$ & 3707676514 & $4.9 \%$ & 8647 & $2.2 \%$ & 3269936523 & $10.2 \%$ & 3138037483 & $9.8 \%$ \\
\hline 436 & $\begin{array}{l}\text { Other financial investment } \\
\text { activities }\end{array}$ & 2527373779 & $3.4 \%$ & 13058 & $3.3 \%$ & 1147680115 & $3.6 \%$ & 1115731997 & $3.5 \%$ \\
\hline 437 & Insurance carriers & 2982262451 & $4.0 \%$ & 7949 & $2.0 \%$ & 717833271.8 & $2.2 \%$ & 1371274129 & $4.3 \%$ \\
\hline 438 & $\begin{array}{l}\text { Insurance agencies, } \\
\text { brokerages, and related } \\
\text { activities }\end{array}$ & 1303721680 & $1.7 \%$ & 8064 & $2.0 \%$ & 544764473 & $1.7 \%$ & 669567657.5 & $2.1 \%$ \\
\hline 440 & Real estate & 7963526367 & $10.6 \%$ & 31192 & $7.8 \%$ & 846378204.3 & $2.6 \%$ & 6591093170 & $20.6 \%$ \\
\hline 449 & $\begin{array}{l}\text { Architectural, engineering, } \\
\text { and related services }\end{array}$ & 1277979858 & $1.7 \%$ & 7748 & $1.9 \%$ & 732993793.5 & $2.3 \%$ & 741639102 & $2.3 \%$ \\
\hline 454 & $\begin{array}{l}\text { Management consulting } \\
\text { services }\end{array}$ & 1801594971 & $2.4 \%$ & 14231 & $3.6 \%$ & 1205290176 & $3.8 \%$ & 1197751532 & $3.7 \%$ \\
\hline 461 & $\begin{array}{l}\text { Management of companies } \\
\text { and enterprises }\end{array}$ & 6862419434 & $9.1 \%$ & 26887 & $6.7 \%$ & 3733640043 & $11.7 \%$ & 4628263227 & $14.4 \%$ \\
\hline 464 & Employment services & 1975736206 & $2.6 \%$ & 25771 & $6.4 \%$ & 1166532901 & $3.6 \%$ & 1690075921 & $5.3 \%$ \\
\hline 475 & Offices of physicians & 1579286011 & $2.1 \%$ & 10323 & $2.6 \%$ & 1149581833 & $3.6 \%$ & 1145355665 & $3.6 \%$ \\
\hline 533 & $\begin{array}{l}{ }^{*} \text { Employment and payroll of } \\
\text { local govt, non-education }\end{array}$ & 2875360596 & $3.8 \%$ & 30665 & $7.7 \%$ & 2483411621 & $7.8 \%$ & 2875360687 & $9.0 \%$ \\
\hline 534 & $\begin{array}{l}\text { * Employment and payroll of } \\
\text { local govt, education }\end{array}$ & 1168110840 & $1.6 \%$ & 19210 & $4.8 \%$ & 1009461243 & $3.2 \%$ & 1168110794 & $3.6 \%$ \\
\hline
\end{tabular}

As it is displayed in figure 6.1. wholesale trade, monetary authorities, and depository credit intermediation, nondepository credit intermediation and related activities, real estate, management of companies and enterprises, and employment and payroll of local government, non-education 
are relatively high in their percentage in all 4 metrics of economic activity. Economic activity of wholesale trade is usually high in any place, since it includes basic needs of the population. Employment and payroll of local government, non-education is also relatively high everywhere since it is part of the governmental system. However, monetary authorities and depository credit intermediation, nondepository credit intermediation and related activities, real estate, management of companies and enterprises can be exclusive to Mecklenburg County and play a significant role for it.

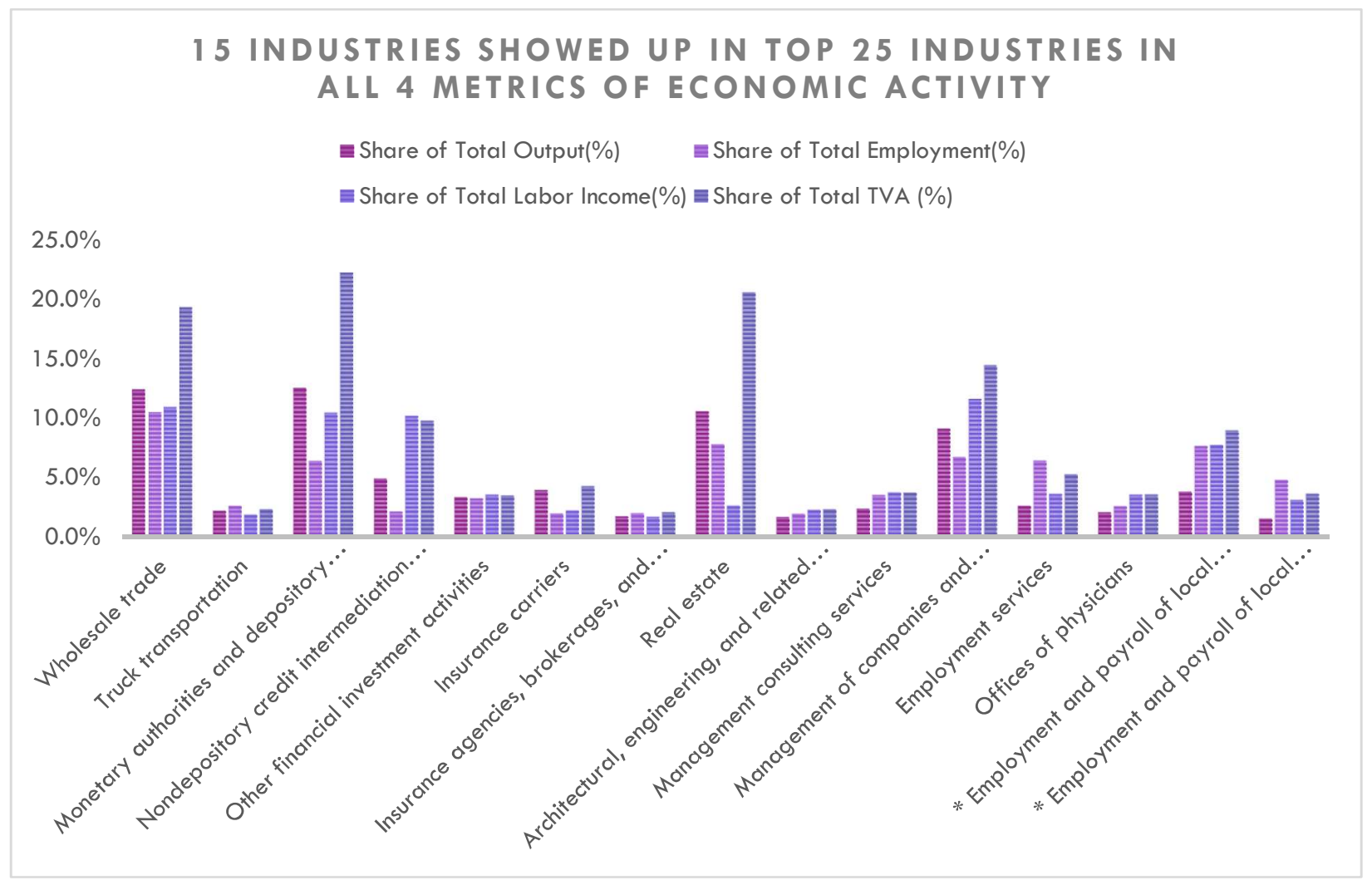

Figure 6.1. Fifteen Industries Showed up in Top 25 Industries in All 4 Metrics of Economic Activity, Source: industry summary data IMPLAN

\section{2.}

Based on table 6.2., other major household appliance manufacturing has the largest concentration in Mecklenburg County. Following that are Software and other prerecorded and record reproducing, Surface active agent manufacturing, and Air and gas compressor manufacturing. 
Based on tables 6.1. and 6.2., Monetary authorities and depository credit intermediation and Non-depository credit intermediation and related activities, that are in top 25 LQ list, are also in top 25 industries across the four metrics of economic activity. Data processing, hosting, and related services that is in top 25 LQ is also in labor income, TVA, and output economic activity metrics (table 6.1.).

Table 6.2. Top 5 industry sectors by $L Q$, Source: IMPLAN

\begin{tabular}{|r|l|c|}
\hline Sector & \multicolumn{1}{|c|}{ Industry } & LQ \\
\hline $\mathbf{3 3 1}$ & Other major household appliance manufacturing & 19.1 \\
\hline $\mathbf{3 2 4}$ & Software and other prerecorded and record reproducing & 18.3 \\
\hline $\mathbf{1 8 1}$ & Surface active agent manufacturing & 15.0 \\
\hline $\mathbf{2 8 8}$ & Air and gas compressor manufacturing & 15.0 \\
\hline $\mathbf{2 8 3}$ & Turbine and turbine generator set units manufacturing & 12.2 \\
\hline
\end{tabular}

\section{3.}

Based on table 6.3., the top three industries in productivity in Mecklenburg County are water, sewage, and other systems, soybean and other oilseed processing, and toilet preparation manufacturing, nonetheless, employment in these industries is very low.

Based on table 6.4., top three industries in terms of job quality in Mecklenburg County are water, sewage, and other systems, toilet preparation manufacturing, and Electric power generation - Solar manufacturing, however, the employment in these industries is again very low.

Surface active agent manufacturing, Electric power generation - Solar, and other major household appliance manufacturing are in both top 25 LQ list and productivity list. Moreover, Electric power generation - Solar, Non-depository credit intermediation and related activities, Software and other prerecorded and record reproducing, and Blank magnetic and optical recording media manufacturing are in both top 25 LQ list and job quality list. 
Table 5.3. Top 5 industries by Productivity (Output per Worker), Source: IMPLAN

\begin{tabular}{|c|c|c|c|c|c|}
\hline Sector & Industry & US (\$) & $\begin{array}{c}\text { North } \\
\text { Carolina } \\
\text { (\$) }\end{array}$ & Meck (\$) & $\begin{array}{l}\text { Employment } \\
\text { (Meck) }\end{array}$ \\
\hline 51 & Water, sewage and other systems & 277174 & 285599 & 13893844 & 4 \\
\hline 71 & Soybean and other oilseed processing & 4447203 & 4451657 & 4415676 & 50 \\
\hline 182 & Toilet preparation manufacturing & 736614 & 1075357 & 3743515 & 4 \\
\hline 161 & Petrochemical manufacturing & 3281536 & 3385894 & 3462587 & 17 \\
\hline 181 & Surface active agent manufacturing & 2175765 & 2957988 & 3415730 & 218 \\
\hline
\end{tabular}

Table 6.4. Top 5 industries by Job Quality, Source: IMPLAN

\begin{tabular}{|r|l|r|r|r|r|}
\hline Sector & Industry & US (\$) & \multicolumn{1}{c|}{$\begin{array}{c}\text { North } \\
\text { Carolina (\$) }\end{array}$} & $\begin{array}{c}\text { Meck (\$) } \\
\text { Employment } \\
\text { (Meck) }\end{array}$ \\
\hline $\mathbf{5 1}$ & Water, sewage and other systems & 92684 & 103127 & 13576042 & 4 \\
\hline $\mathbf{1 8 2}$ & Toilet preparation manufacturing & 90893 & 74776 & 3337108 & 4 \\
\hline $\mathbf{4 4}$ & Electric power generation - Solar & 166185 & 179503 & 3281059 & 0 \\
\hline $\mathbf{1 5 8}$ & $\begin{array}{l}\text { Asphalt shingle and coating materials } \\
\text { manufacturing }\end{array}$ & 250675 & 112019 & 2486902 & \\
\hline
\end{tabular}

\section{4 .}

Based on table 6.5., the largest exporting industries in Mecklenburg County are monetary authorities and depository credit intermediation, wholesale trade, management of companies and enterprises, real estate, and non-depository credit intermediation and related activities, respectively. Intermediate imports are also reported in this table to provide insights into the degree to which that industry's product is being imported into the region.

Based on table 6.6., the largest importing industries in Mecklenburg County are air transportation, wholesale trade, management of companies and enterprises, truck transportation, and wireless telecommunications carriers (except satellite).

None of the top three industries in terms of productivity, job quality, and LQ in Mecklenburg County made the top 25 industries in export and import. However, twelve industries out of fifteen that are in all four metrics of economic activity are in the top 25 export industries. 
Among those 12 are Monetary authorities and depository credit intermediation, and Nondepository credit intermediation and related activities which are also among the top 25 in terms of LQ. Monetary authorities show up again among the top importers in the county.

Two of these industries, Monetary authorities and depository credit intermediation, and Nondepository credit intermediation and related activities are also in the top 25 LQ list. Moreover, seven industries out of fifteen that are in all four metrics of economic activity are in the top 25 import industries:

- Monetary authorities and depository credit intermediation

- Wholesale trade

- Real estate

- Management of companies and enterprises

- Insurance carriers

- Other financial investment activities

- Truck transportation

Table 6.5. Top 15 Mecklenburg County export industries, Source: IMPLAN

\begin{tabular}{|c|c|c|c|c|c|}
\hline Sector & Industry & $\begin{array}{c}\text { Total } \\
\text { Exports (\$) }\end{array}$ & $\begin{array}{l}\text { Intermediate } \\
\text { Imports (\$) }\end{array}$ & Employment & $\begin{array}{l}\text { Labor Income } \\
\text { Per Worker } \\
\text { (\$) }\end{array}$ \\
\hline 433 & $\begin{array}{l}\text { Monetary authorities and depository credit } \\
\text { intermediation }\end{array}$ & 7161862483 & 307622615 & 25592 & 131099 \\
\hline 395 & Wholesale trade & 5457662842 & 790003752 & 41857 & 83282 \\
\hline 461 & $\begin{array}{l}\text { Management of companies and } \\
\text { enterprises }\end{array}$ & 5214275635 & 600830584 & 26887 & 138865 \\
\hline 440 & Real estate & 3571434693 & 296244076 & 31192 & 27135 \\
\hline 434 & $\begin{array}{l}\text { Nondepository credit intermediation and } \\
\text { related activities }\end{array}$ & 2831641493 & 118319876 & 8647 & 378172 \\
\hline 408 & Air transportation & 1978152557 & 956620633 & 6863 & 73239 \\
\hline 430 & $\begin{array}{l}\text { Data processing, hosting, and related } \\
\text { services }\end{array}$ & 1773254395 & 403724097 & 7237 & 113825 \\
\hline 437 & Insurance carriers & 1220403509 & 341726056 & 7949 & 90308 \\
\hline 464 & Employment services & 1055790996 & 54516324 & 25771 & 45265 \\
\hline 436 & Other financial investment activities & 1011685440 & 214998286 & 13058 & 87890 \\
\hline 454 & Management consulting services & 992845185.7 & 143159064 & 14231 & 84695 \\
\hline 283 & $\begin{array}{l}\text { Turbine and turbine generator set units } \\
\text { manufacturing }\end{array}$ & 911055939.5 & 380555605 & 1447 & 114995 \\
\hline 411 & Truck transportation & 836127613.7 & 479865158 & 10457 & 57875 \\
\hline 181 & Surface active agent manufacturing & 732571444.8 & 143495820 & 218 & 170346 \\
\hline
\end{tabular}


Table 6.6. Top 15 Mecklenburg County import industries, Source: IMPLAN

\begin{tabular}{|c|c|c|c|c|c|}
\hline Sector & Industry & $\begin{array}{c}\text { Total } \\
\text { Exports }(\$)\end{array}$ & $\begin{array}{l}\text { Intermediate } \\
\text { Imports (\$) }\end{array}$ & Employment & $\begin{array}{l}\text { Labor Income } \\
\text { Per Worker } \\
\text { (\$) }\end{array}$ \\
\hline 408 & Air transportation & 1978152557 & 956620633 & 41857 & 83282 \\
\hline 395 & Wholesale trade & 5457662842 & 790003752 & 1041 & 128884 \\
\hline 461 & Management of companies and enterprises & 5214275635 & 600830584 & 0 & 0 \\
\hline 411 & Truck transportation & 836127614 & 479865158 & 6863 & 73239 \\
\hline 428 & $\begin{array}{l}\text { Wireless telecommunications carriers } \\
\text { (except satellite) }\end{array}$ & 516029403 & 476690347 & 4148 & 88762 \\
\hline 430 & $\begin{array}{l}\text { Data processing, hosting, and related } \\
\text { services }\end{array}$ & 1773254395 & 403724097 & 1137 & 67826 \\
\hline 283 & $\begin{array}{l}\text { Turbine and turbine generator set units } \\
\text { manufacturing }\end{array}$ & 911055940 & 380555605 & 376 & 103605 \\
\hline 437 & Insurance carriers & 1220403509 & 341726056 & 13058 & 87890 \\
\hline 426 & Cable and other subscription programming & 526245574 & 338184446 & 10457 & 57875 \\
\hline 61 & $\begin{array}{l}\text { Construction of other new residential } \\
\text { structures }\end{array}$ & 293336 & 326540708 & 3022 & 68054 \\
\hline 433 & $\begin{array}{l}\text { Monetary authorities and depository credit } \\
\text { intermediation }\end{array}$ & 7161862483 & 307622615 & 7237 & 113825 \\
\hline 427 & Wired telecommunications carriers & 459349892 & 303725367 & 1578 & 169719 \\
\hline 441 & Owner-occupied dwellings & 61 & 298674115 & 31192 & 27135 \\
\hline 49 & Electric power transmission and distribution & 305593872 & 296876823 & 961 & 129915 \\
\hline 440 & Real estate & 3571434693 & 296244076 & 7949 & 90308 \\
\hline
\end{tabular}

6.5 .

Based on this analysis, since two of these industries, Monetary authorities and depository credit intermediation, and Management of companies and enterprises are in the top 25 industries across the four metrics of economic activity, and also in the list of largest importing and exporting industries in Mecklenburg County, it appears that these two industries are particularly important to the local economy of Mecklenburg County.

The top three importing industries are Air Transportation, Wholesale Trade, and Management of Companies and Enterprises. Two industries that I identified are Monetary authorities and depository credit intermediation, and Management of Companies and Enterprises. Table 6.7. displays the top imported commodities for these industries. 
The top 3 importing industries also show up in the top export industries (see table 6.5.). Management of companies and enterprises, and whole sale trade show up in all four metrics of economic activity and Air transportation shows up in three metrics of economic activity (industry output, labor income, TVA) (see table 6.1. and appendix).

From two industries, I identified in section 6.5., (Monetary authorities and depository credit intermediation, and Management of Companies and Enterprises), Management of companies and enterprises is one of the main importing industries that shows in industry import matrix. However, it is not part of the suppliers of the importing industries.

Based on table 6.7. two main imported commodities for Monetary authorities and depository credit intermediation, and Management of Companies and Enterprises are Advertising, public relations, and related services and Noncomparable imports. Advertising, public relations, and related services is also the biggest imported industry for Wholesale trade. Noncomparable imports is also one of the main imported industries for Air transportation. Refined petroleum products also is the main imported commodity for Air transportation, Wholesale trade, and Management of companies and enterprises.

Thus, based on these analyses, Management of companies and enterprises is a strong industry for the county, also, Air transportation has shown its importance for Mecklenburg County with its imports, and as a hub, they worth targeting for further study. 


\begin{tabular}{|c|c|c|c|}
\hline Importing Industry & Code & Commodities Imported & $\begin{array}{l}\text { Estimated } \\
\text { Imports (\$) }\end{array}$ \\
\hline \multirow[t]{5}{*}{ Air transportation } & 3156 & Refined petroleum products & 565400367 \\
\hline & 3530 & Noncomparable imports & 207533324 \\
\hline & 3414 & $\begin{array}{l}\text { Scenic and sightseeing transportation services and } \\
\text { support activities for transportation }\end{array}$ & 85372614 \\
\hline & 3445 & $\begin{array}{l}\text { Commercial and industrial machinery and equipment } \\
\text { rental and leasing services }\end{array}$ & 33045132 \\
\hline & 3359 & Other aircraft parts and auxiliary equipment & 18482973 \\
\hline \multirow[t]{5}{*}{ Wholesale trade } & 3457 & Advertising, public relations, and related services & 98076803 \\
\hline & 3416 & Warehousing and storage services & 56647494 \\
\hline & 3156 & Refined petroleum products & 47985272 \\
\hline & 3414 & $\begin{array}{l}\text { Scenic and sightseeing transportation services and } \\
\text { support activities for transportation }\end{array}$ & 35745910 \\
\hline & 3415 & Couriers and messengers services & 34128564 \\
\hline \multirow{5}{*}{$\begin{array}{l}\text { Management of } \\
\text { companies and } \\
\text { enterprises }\end{array}$} & 3457 & Advertising, public relations, and related services & 112929424 \\
\hline & 3530 & Noncomparable imports & 39908749 \\
\hline & 3156 & Refined petroleum products & 30847030 \\
\hline & 3446 & Leasing of nonfinancial intangible assets & 27726511 \\
\hline & 3447 & Legal services & 22671967 \\
\hline \multirow{5}{*}{$\begin{array}{c}\text { Monetary Authority and } \\
\text { Depository }\end{array}$} & 3457 & Advertising, public relations, and related services & 50789700.97 \\
\hline & 3515 & Business and professional services & 30907723.84 \\
\hline & 3062 & Maintained and repaired nonresidential structures & 24355968.84 \\
\hline & 3499 & Hotels and motel services, including casino hotels & 20725167.37 \\
\hline & 3530 & Noncomparable imports & 18529721.09 \\
\hline
\end{tabular}

Figure 6.7. Industry import matrix: top 5 imported commodities for the top three importing industries and the industries are identified in section 6.5., Source: IMPLAN 


\section{SWOT}

- growing population

- high rate of labor force

- decreasing unemployment rate

- educational attainment

- industry mix, occupational mix

- transportation infrustructure: air, highway, rail

- largest occupations: OfficeAdmin, Sales, Food, BusinessFinance, Transportation

- high share of Output, Emp, LI, TVA: Monetory, RealEstate, Management, nondepository

- high export industries: Monetary, Wholesale, Management

- aging population

- educational attainment

- developing region not a developed region

- declining occupations: OfficeAdminSup., Management, Production, Construction, Building Maint., ...

- high import industries: Air transport, Wholesale, Management

\section{- growing population}

- decreasing unemployment rate

- education

- increasing employment rate

- industry mix

- transportation infrustructure: air, highway, rail

- growing occupations: BusinessFinance, Computer, Protective services, Sales, Healthcare

- increasing median wage occupations: Management, Farming, Business, Architecture, CommunityService

- Increasing LQ: Educ, Arts, Info, Prof, Health, Accomod, Finance

- high export industries: Monetary, Wholesale, Management

- educational attainment

- developing region not a developed region

- declining occupations: OfficeAdminSup., Management, Production, Construction, BuildingMaint.

- high import industries: Air transport, Wholesale, Management, Monetary

- growing population

- aging populaiton

- declining occupations: OfficeAdminSup., Management, Production, Construction, Building Maint., ...

- decreasing median wage occupations: Legal, healthcare, PersonalCare, Building, Food

- decreasing LQ: Management, Wholesale, Transport, Manufacturing 


\section{8. summary}

The Mecklenburg County economy is strong and robust. There are several industries that are dominant in the region including Office and administrative services, Sales, Food, Business and financial, Transportation with high share of employment, and Monetary, Real Estate, Management, non-depository with high share of four metrics of economic activity and Monetary, Wholesale, Management with high share of export. However, a number of industries have shown significant growth over the past few years.

Looking into the future, it does not appear that manufacturing in general to be the engine of new economic growth that it once was. As we see in the growing occupations, Mecklenburg County moves toward more service oriented industries such as business and financial operations, Protective services, Sales and related.

Throughout this analysis, we found some disconnects in the local economy. Disconnects are instances where local production is not being used to satisfy local demand. One large disconnect identified in this study is between the Management of companies and enterprises and legal services. While management of companies and enterprises imports legal services, at the same time legal services are exported to out of the region.

When there is a large demand in the local economy for a product or service, and they are not supplied locally, industries need to import those commodities, and it means that there is a gap in the local economy. One gap identified in this study is in the refined petroleum products and it is not locally available and must be imported. Another gap is advertising, public relations, and related services.

We have used several tools and sources to identify local strengths and weaknesses and figure out the points of opportunities and threats. Based on the analysis through the entire report, and the 
SWOT analysis, those areas with the opportunity of further development are those ones that we have the strength for them in the county. Since Mecklenburg County has a growing population, high rate of labor force, increasing employment rate, industry mix, and access to infrastructure such as air transportation and highway and rail roads, we can target those industries that are highly important and need to import a lot of commodities. These industries include air transportation, management of companies and enterprises, and monetary authority and depository. These are the largest importing industries in the region that we use as a target for economic development. By locally providing the demand for these industries we can reduce the amount of money that is spent out of the region and keep and use it for the local economy.

Some of the weaknesses of the region that might affect the success of these targeted industries are the aging population of the county and relatively low educational attainment. Also, some threats that may put the region at risk are decreasing location quotient of management, wholesale trade, and transportation which make the process of improving at difficulty.

\section{Appendix:}

\begin{tabular}{|c|c|c|c|}
\hline Sector & Industry & Output (\$) & $\begin{array}{l}\text { Share of } \\
\text { Total (\%) }\end{array}$ \\
\hline 433 & Monetary authorities and depository credit intermediation & 9450167969 & $12.6 \%$ \\
\hline 395 & Wholesale trade & 9328416992 & $12.4 \%$ \\
\hline 440 & Real estate & 7963526367 & $10.6 \%$ \\
\hline 461 & Management of companies and enterprises & 6862419434 & $9.1 \%$ \\
\hline 434 & Non-depository credit intermediation and related activities & 3707676514 & $4.9 \%$ \\
\hline 441 & Owner-occupied dwellings & 3587953369 & $4.8 \%$ \\
\hline 437 & Insurance carriers & 2982262451 & $4.0 \%$ \\
\hline 533 & * Employment and payroll of local govt, non-education & 2875360596 & $3.8 \%$ \\
\hline 436 & Other financial investment activities & 2527373779 & $3.4 \%$ \\
\hline 408 & Air transportation & 2439408691 & $3.2 \%$ \\
\hline 430 & Data processing, hosting, and related services & 2370623047 & $3.1 \%$ \\
\hline 464 & Employment services & 1975736206 & $2.6 \%$ \\
\hline 454 & Management consulting services & 1801594971 & $2.4 \%$ \\
\hline 428 & Wireless telecommunications carriers (except satellite) & 1759413818 & $2.3 \%$ \\
\hline 427 & Wired telecommunications carriers & 1666092651 & $2.2 \%$ \\
\hline
\end{tabular}




\begin{tabular}{|c|c|c|c|}
\hline 411 & Truck transportation & 1658724121 & $2.2 \%$ \\
\hline 49 & Electric power transmission and distribution & 1591802124 & $2.1 \%$ \\
\hline 475 & Offices of physicians & 1579286011 & $2.1 \%$ \\
\hline 502 & Limited-service restaurants & 1385435669 & $1.8 \%$ \\
\hline 426 & Cable and other subscription programming & 1370865723 & $1.8 \%$ \\
\hline 451 & Custom computer programming services & 1349580444 & $1.8 \%$ \\
\hline 438 & Insurance agencies, brokerages, and related activities & 1303721680 & $1.7 \%$ \\
\hline 447 & Legal services & 1291736084 & $1.7 \%$ \\
\hline 449 & Architectural, engineering, and related services & 1277979858 & $1.7 \%$ \\
\hline 534 & * Employment and payroll of local govt, education & 1168110840 & $1.6 \%$ \\
\hline
\end{tabular}

Figure 9.1. Top 25 industries by output, Source: IMPLAN

\begin{tabular}{|c|c|c|c|}
\hline Sector & Industry & Employment & $\begin{array}{l}\text { Share of } \\
\text { Total (\%) }\end{array}$ \\
\hline 395 & Wholesale trade & 41857 & $10.5 \%$ \\
\hline 440 & Real estate & 31192 & $7.8 \%$ \\
\hline 533 & * Employment and payroll of local govt, non-education & 30665 & $7.7 \%$ \\
\hline 461 & Management of companies and enterprises & 26887 & $6.7 \%$ \\
\hline 464 & Employment services & 25771 & $6.4 \%$ \\
\hline 433 & Monetary authorities and depository credit intermediation & 25592 & $6.4 \%$ \\
\hline 501 & Full-service restaurants & 22058 & $5.5 \%$ \\
\hline 534 & * Employment and payroll of local govt, education & 19210 & $4.8 \%$ \\
\hline 502 & Limited-service restaurants & 18604 & $4.6 \%$ \\
\hline 454 & Management consulting services & 14231 & $3.6 \%$ \\
\hline 436 & Other financial investment activities & 13058 & $3.3 \%$ \\
\hline 503 & All other food and drinking places & 12737 & $3.2 \%$ \\
\hline 405 & Retail - General merchandise stores & 11101 & $2.8 \%$ \\
\hline 468 & Services to buildings & 11090 & $2.8 \%$ \\
\hline 411 & Truck transportation & 10457 & $2.6 \%$ \\
\hline 475 & Offices of physicians & 10323 & $2.6 \%$ \\
\hline 532 & * Employment and payroll of state govt, education & 9942 & $2.5 \%$ \\
\hline 509 & Personal care services & 9062 & $2.3 \%$ \\
\hline 400 & Retail - Food and beverage stores & 8766 & $2.2 \%$ \\
\hline 434 & Non-depository credit intermediation and related activities & 8647 & $2.2 \%$ \\
\hline 438 & Insurance agencies, brokerages, and related activities & 8064 & $2.0 \%$ \\
\hline 437 & Insurance carriers & 7949 & $2.0 \%$ \\
\hline 467 & Investigation and security services & 7774 & $1.9 \%$ \\
\hline 449 & Architectural, engineering, and related services & 7748 & $1.9 \%$ \\
\hline 58 & Construction of other new nonresidential structures & 7340 & $1.8 \%$ \\
\hline
\end{tabular}

Figure 9.2. Top 25 industries by employment, Source: IMPLAN 


\begin{tabular}{|c|c|c|c|}
\hline Sector & Industry & Income (\$) & $\begin{array}{l}\text { Share of } \\
\text { Total (\%) }\end{array}$ \\
\hline 461 & Management of companies and enterprises & 3733640043 & $11.7 \%$ \\
\hline 395 & Wholesale trade & 3485928589 & $10.9 \%$ \\
\hline 433 & Monetary authorities and depository credit intermediation & 3355082397 & $10.5 \%$ \\
\hline 434 & Non-depository credit intermediation and related activities & 3269936523 & $10.2 \%$ \\
\hline 533 & ${ }^{*}$ Employment and payroll of local govt, non-education & 2483411621 & $7.8 \%$ \\
\hline 454 & Management consulting services & 1205290176 & $3.8 \%$ \\
\hline 464 & Employment services & 1166532901 & $3.6 \%$ \\
\hline 475 & Offices of physicians & 1149581833 & $3.6 \%$ \\
\hline 436 & Other financial investment activities & 1147680115 & $3.6 \%$ \\
\hline 435 & Securities and commodity contracts intermediation and brokerage & 1009795303 & $3.2 \%$ \\
\hline 534 & * Employment and payroll of local govt, education & 1009461243 & $3.2 \%$ \\
\hline 440 & Real estate & 846378204.3 & $2.6 \%$ \\
\hline 430 & Data processing, hosting, and related services & 823700832.4 & $2.6 \%$ \\
\hline 462 & Office administrative services & 812234380.7 & $2.5 \%$ \\
\hline 449 & Architectural, engineering, and related services & 732993793.5 & $2.3 \%$ \\
\hline 451 & Custom computer programming services & 719865711.2 & $2.2 \%$ \\
\hline 437 & Insurance carriers & 717833271.8 & $2.2 \%$ \\
\hline 447 & Legal services & 629217506.4 & $2.0 \%$ \\
\hline 411 & Truck transportation & 605178665.2 & $1.9 \%$ \\
\hline 448 & Accounting, tax preparation, bookkeeping, and payroll services & 594390686 & $1.9 \%$ \\
\hline 438 & Insurance agencies, brokerages, and related activities & 544764473 & $1.7 \%$ \\
\hline 532 & ${ }^{*}$ Employment and payroll of state govt, education & 521366455.1 & $1.6 \%$ \\
\hline 408 & Air transportation & 502637621.5 & $1.6 \%$ \\
\hline 501 & Full-service restaurants & 481771518.7 & $1.5 \%$ \\
\hline 482 & Hospitals & 481528781.9 & $1.5 \%$ \\
\hline
\end{tabular}

Figure 9.3. Top 25 industries by labor income, Source: IMPLAN

\begin{tabular}{|r|l|r|r|}
\hline Sector & \multicolumn{1}{|c|}{ Industry } & $\begin{array}{r}\text { Total Value Added } \\
\text { (\$) }\end{array}$ & $\begin{array}{c}\text { Share of } \\
\text { Total }(\%)\end{array}$ \\
\hline $\mathbf{4 3 3}$ & Monetary authorities and depository credit intermediation & 7120356552 & $14.0 \%$ \\
\hline $\mathbf{4 4 0}$ & Real estate & 6591093170 & $13.0 \%$ \\
\hline $\mathbf{3 9 5}$ & Wholesale trade & 6191266846 & $12.2 \%$ \\
\hline $\mathbf{4 6 1}$ & Management of companies and enterprises & 4628263227 & $9.1 \%$ \\
\hline $\mathbf{4 3 4}$ & Non-depository credit intermediation and related activities & 3138037483 & $6.2 \%$ \\
\hline $\mathbf{5 3 3}$ & * Employment and payroll of local govt, non-education & 2875360687 & $5.7 \%$ \\
\hline $\mathbf{4 4 1}$ & Owner-occupied dwellings & 2427774017 & $4.8 \%$ \\
\hline $\mathbf{4 6 4}$ & Employment services & 1690075921 & $3.3 \%$ \\
\hline $\mathbf{4 3 7}$ & Insurance carriers & 1371274129 & $2.7 \%$ \\
\hline $\mathbf{4 5 4}$ & Management consulting services & 1197751532 & $2.4 \%$ \\
\hline $\mathbf{5 3 4}$ & * Employment and payroll of local govt, education & 1168110794 & $2.3 \%$ \\
\hline $\mathbf{4 7 5}$ & Offices of physicians & 1145355665 & $2.3 \%$ \\
\hline & & &
\end{tabular}




\begin{tabular}{|r|l|r|r|}
\hline $\mathbf{4 3 6}$ & Other financial investment activities & 1115731997 & $2.2 \%$ \\
\hline $\mathbf{4 0 8}$ & Air transportation & 1099424426 & $2.2 \%$ \\
\hline $\mathbf{4 3 0}$ & Data processing, hosting, and related services & 1063047564 & $2.1 \%$ \\
\hline $\mathbf{4 4 7}$ & Legal services & 1023029287 & $2.0 \%$ \\
\hline $\mathbf{4 5 1}$ & Custom computer programming services & 951346504.2 & $1.9 \%$ \\
\hline $\mathbf{4 6 2}$ & Office administrative services & 789926774.5 & $1.6 \%$ \\
\hline $\mathbf{5 0 2}$ & Limited-service restaurants & 789318014.1 & $1.6 \%$ \\
\hline $\mathbf{4 4 8}$ & Accounting, tax preparation, bookkeeping, and payroll services & 753782935.1 & $1.5 \%$ \\
\hline $\mathbf{4 1 1}$ & Truck transportation & 741947359.1 & $1.5 \%$ \\
\hline $\mathbf{4 4 9}$ & Architectural, engineering, and related services & 741639102 & $1.5 \%$ \\
\hline $\mathbf{4 9}$ & Electric power transmission and distribution & 724951213.6 & $1.4 \%$ \\
\hline $\mathbf{4 2 7}$ & Wired telecommunications carriers & 697248844 & $1.4 \%$ \\
\hline $\mathbf{4 3 8}$ & Insurance agencies, brokerages, and related activities & 66967657.5 & $1.3 \%$ \\
\hline $\mathbf{9 . 4}$ & Top 25 industries by total value added, Source IMPLAN & 7 \\
\hline
\end{tabular}

Figure 9.4. Top 25 industries by total value added, Source: IMPLAN

\section{Reference:}

- Bacot, Hunter. 2008. "Civic Culture as a Policy Premise: Appraising Charlotte's Civic Culture." Journal of Urban Affairs 30 (4): 389-417. doi:10.1111/j.1467-9906.2008.00405.x.

- Carman, Joanne G., Suzanne M. Leland, and Amanda J. Wilson. 2010. "Crisis in Leadership or Failure to Plan?” Nonprofit Management and Leadership 21 (1): 93-111. doi:10.1002/nml.20014.

- Weinstein, Jeffrey M. 2016. "The Impact of School Racial Compositions on Neighborhood Racial Compositions: Evidence from School Redistricting.” Economic Inquiry 54 (3): 1365-82. doi:10.1111/ecin.12329.

- Charlotte Energy Sector, Charlotte Chamber's Economic Development

- Charlotte Douglas International Airport:

http://www.cltairport.com/AboutCLT/Pages/EconomicImpact.aspx 